\title{
Audit Committee Financial Expertise, Competing Corporate Governance Mechanisms, and Earnings Management
}

\author{
Joseph V. Carcello \\ University of Tennessee
}

Carl W. Hollingsworth

University of Tennessee

April Klein

New York University

Terry L. Neal

University of Tennessee

February 2006 


\title{
Audit Committee Financial Expertise, Competing Corporate Governance Mechanisms, and Earnings Management
}

\begin{abstract}
A prime objective of the Sarbanes-Oxley Act and recent changes to stock exchange listing standards is to improve the quality of financial reporting. We examine the associations between audit committee financial expertise and alternate corporate governance mechanisms and earnings management. We find that both accounting and certain types of non-accounting financial expertise reduce earnings management for firms with weak alternate corporate governance mechanisms, but that independent audit committee members with financial expertise are most effective in mitigating earnings management. Importantly we find that alternate corporate governance mechanisms are an effective substitute for audit committee financial expertise in constraining earnings management. Finally, we find either no association or a positive association between financial expertise and real earnings management. Our results suggest that alternate governance approaches are equally effective in improving the quality of financial reporting, and that firms should have the flexibility to design the particular set of governance mechanisms that best fit their unique situations.
\end{abstract}




\section{Audit Committee Financial Expertise, Competing Corporate Governance Mechanisms, and Earnings Management}

\section{Introduction}

The U.S. Congress, in enacting the Sarbanes-Oxley Act of 2002 (SOX), and the New York Stock Exchange (NYSE) and NASDAQ, in modifying their listing requirements in December 1999, place great reliance on the company's audit committee as a means of protecting the integrity of the financial reporting system. However, while these rules provide clear standards on audit committee independence and number of committee members, they are ambiguous on the definition and even the need for an audit committee financial expert. Thus, the desirability and efficacy of how an audit committee financial expert improves a firm's corporate governance environment and its financial reporting process is an open question.

We contribute to this debate by examining the role that an audit committee financial expert plays in mitigating earnings management for a broad sample of NYSE and NASDAQ firms in 2003, the first year that public companies are required to designate whether they have a financial expert on the audit committee and the name of that financial expert. We choose earnings management as our metric because one of the main goals of SOX is to limit earnings manipulations (see SEC, 2003c). In support of this, $\mathrm{Li}$ et al. (2006) find that the positive stock price reaction to events surrounding the passage of SOX in 2002 are related directly to the firm's previous earnings management. Further, Cohen et al. (2005) report a significant drop in earnings management following SOX, although they also find that managers increased "real" earnings management (e.g., a reduction in $\mathrm{R} \& \mathrm{D}$ or advertising expenses) during the same time period. 
Our study focuses primarily on two issues: (1) discerning among the differing definitions of "financial expertise" and (2) the interactions between having an audit committee financial expert and other corporate governance mechanisms. The motivation behind examining these issues is that SOX, the SEC, and the stock exchanges provide a great deal of flexibility to firms in choosing the role that the financial expert plays within their overall corporate governance structures.

SOX does not require a firm to include a financial expert on its audit committee; it merely mandates that the firm discloses in its filings whether the committee has such an expert, and if not to explain why. SOX also assigned the designation of what constitutes a financial expert to the SEC, although the Act described a financial expert as someone with experience in preparing or auditing financial statements and the firm's internal controls. Initially, the SEC proposed this limited definition of a financial expert. However, in response to concerns from the corporate community, the SEC greatly expanded its definition to include shaded degrees of expertise. As a result, firms are able to designate a financial expert from a larger cadre of directors, including top managers from other companies, investment bankers, venture capitalists, and others.

In addition to SOX, the NYSE and NASDAQ have their sets of corporate governance listing standards. Beginning in 1999, the NYSE and the NASDAQ ostensibly require a listed firm to include a financial expert on its audit committee. However, a perusal of the exchanges' definitions of whom qualifies as an expert reveals that they are broadly-based, thereby setting a low threshold for inclusion. Further, while SOX is silent on other board characteristics, the exchanges' listing standards provide for alternative board governance mechanisms, such as a majority of independent board members and requiring the board nominating and executive compensation functions to be enacted by 
independent board members only. Thus the rules and regulations surrounding audit committee financial experts are quite expansive, suggesting a wide degree of substitutability among alternative corporate governance mechanisms as well as abilities among directors to act as financial experts.

Our results both support and reject these conjectures. First, there is a significant relation between having a financial expert on the audit committee and a lower level of earnings management. However, this association is most pronounced when the designated financial expert has prior work experience in accounting, for example, $\mathrm{s}(\mathrm{he})$ is a CPA, former $\mathrm{CFO}$, corporate treasurer or controller. In contrast, we find no significant relation between earnings management and the SEC's or the exchanges' expanded definitions of financial expertise, for example, s(he) is/was a CEO of another firm, banker, or venture capitalist. However, when we split non-accounting financial experts into two groups, senior business executives and other non-accounting experts, we find a negative relation between other non-accounting financial experts and earnings management, but no relation between earnings management and senior business executives of other firms. Moreover, we also find that the relation between earnings management and an accounting financial expert and between earnings management and other non-accounting financial experts is stronger when these experts are independent. Second, there is a trade-off between having a restrictively-defined financial expert and other corporate governance monitoring mechanisms. We find that having an accountingbased financial expert on the audit committee or good corporate governance (later defined) lessens earnings management. Combining the two has no incremental tangible effects on reducing earnings management. In contrast, and consistent with our first finding, non-accounting financial experts neither add nor detract from a firm's good 
corporate governance practices when applied to managing earnings. We therefore conclude that SOX's disclosure requirements and the exchanges' flexible listing standards on audit committee financial experts are adequate mechanisms to ensure the integrity of the corporate reporting system.

We also examine whether the presence of an audit committee financial expert is associated with real earnings management. Graham et al. $(2005 ; 2006)$ provide details on a Fall 2003 survey of chief financial officers (CFOs) about earnings management. They report that the vast majority of CFOs consider EPS to be an important reported number and that CFOs are willing to engage in real earnings management to meet earnings expectations or to smooth earnings. Cohen et al. (2005) provide evidence that since the enactment of SOX, GAAP earnings management has declined but real earnings management has increased. Since real earnings management is within the bounds of GAAP, we argue that it is not in the purview of the audit committee. In fact, we argue that the postponement of real investments may fly below the radar screen of the entire board of directors. Thus, we predict and find no significantly negative association between financial expertise, other corporate governance attributes and real earnings management.

Our paper contributes to several strands of research. There is a growing empirical literature documenting the effects that SOX and market regulations have had on earnings management (e.g., see Cohen et al., 2005; Klein, 2002a; Carver, 2005). ${ }^{1}$ Further, within this body of research, there are papers examining the role that audit committee financial expertise has on auditor independence (Carcello and Neal, 2003), fraud and earnings restatements (Abbott et al., 2004; Agrawal and Chadha, 2005), financial reporting quality

\footnotetext{
${ }^{1}$ See DeFond and Francis (2005) for an excellent summary of the audit research before and after the enactment of SOX.
} 
(Felo et al., 2003) and earnings management itself (Xie et al., 2003). The financial expert papers yield different conclusions, primarily because they use different definitions of financial expertise. Our paper provides evidence that directors with direct experience in creating financial reports are better able to curb earnings management than those directors whose experience is as a CEO/President of another firm. This finding is consistent with DeFond et al. (2005) who find that the market reacts positively to the appointment of a financial expert with prior accounting experience but has no reaction to the appointment of a non-accounting financial expert (DeFond et al. define a nonaccounting financial expert as a CEO or president of a for-profit corporation).

Our paper also contributes to the emerging literature on the costs of regulation and SOX itself on firms (e.g., see Ribstein, 2002; Holmstrom and Kaplan, 2003; Romano, 2005; Zhang, 2005; Li et al., 2006). While we do not directly measure the costs of having an audit committee financial expert, we present evidence consistent with the view that allowing firms discretion in selecting from a menu of corporate governance choices is a viable option towards achieving investor protection. This finding is consistent with Klein (2002b), DeFond et al. (2005), and Carver (2005), who examine the contextual role of various audit committee characteristics.

We also contribute to the growing literature on "real" vs. "GAAP" earnings management (Roychowdhury, 2005; Cohen et al., 2005; Graham et al., 2005; 2006). SOX was enacted to improve the reliability of the financial reporting system. It does not deal with the more subtle, but equally pervasive, management of earnings through the delay or cutting back of real investments within the firm. Our results show that, as expected, the presence of a financial expert on the audit committee is negatively related to "GAAP" earnings management but is not similarly related to "real" earnings 
management. In fact, although we find no significant relation between audit committee financial experts and management of abnormal production costs, we do find a significantly positive relation between accounting financial experts and earnings management via abnormal discretionary expenditures. Therefore, other means besides government regulation may be needed to curb the latter type of managerial behavior.

Section 2 provides further background on the relation between earnings management and financial expertise and other corporate governance mechanisms, and discusses the hypotheses between these factors and real earnings management. Section 3 describes our research method and Section 4 presents our results. Section 5 presents other analyses, and the results of testing the relation between real earnings management and financial expertise and other governance mechanisms are presented in Section 6 . Section 7 summarizes and recognizes the limitations of our study.

\section{Background and Hypotheses}

\subsection{Financial expertise and earnings management}

The preamble to SOX is one line, stating that the purpose of the Act is to "protect investors by improving the accuracy and reliability of corporate disclosures pursuant to the security laws, and for other purposes" (SOX 2002). Although there are several ways to gauge the accuracy and reliability of corporate disclosures, we examine the effects of an audit committee financial expert on earnings management, where we define earnings management as abnormal accruals.

Section 407 of SOX requires public companies to disclose whether a financial expert is included on the audit committee. This requirement reflects a belief on the part of Congress that “... the effectiveness of the audit committee depends in part on its 
members' knowledge of and experience in auditing and financial matters" (U.S. Senate 2002, 32). Section 407 also delegated to the SEC the authority to define financial expertise.

SOX was enacted on July 30, 2002. In Section 407, the SEC was given a deadline of 90 days after the enactment of the Act to propose rules to implement this section and an additional 90 days thereafter to issue its final rules. On October 22, 2002, the SEC issued its proposal on 407 , including a tentative definition of a "financial expert," which mimicked the language in SOX (SEC 2002). Specifically:

"The Sarbanes-Oxley Act requires the Commission, in defining the term 'financial expert,' to consider whether a person has, through education and experience as a public accountant or auditor or a principal financial officer, or controller, or principal accounting officer of an issuer, or from a position involving the performance of similar functions:

1. an understanding of generally accepted accounting principles and financial statements;

2. experience in (a) the preparation or auditing of financial statements of generally comparable issuers; and (b) the application of such principles in connection with the accounting for estimates, accruals, and reserves;

3. experience with internal accounting controls; and

4. an understanding of the audit committee functions.

We label a director on the audit committee with these qualifications as an accounting financial expert since the director is required to have actual experience in accounting. The SEC proposal also broadened SOX by proposing that companies disclose whether the designated financial expert is an independent board member, and if not, an explanation as to why not.

On January 23, 2003, the SEC issued its final rules on implementing Section 407 (SEC 2003a). These rules became effective on March 31, 2003 (SEC 2003b). Specifically, a company is required to disclose whether it has at least one "audit committee financial expert" (ACFE) serving on its audit committee, and if so, the name 
of the expert and whether the expert is independent of management. These rules are generally consistent with the October proposal.

One major change from the original SEC rule proposal to the final rule was a dramatic expansion in the definition of a financial expert. The expansion in the definition of a financial expert was in response to the following concerns: (1) difficulty in attracting a financial expert under the original (restricted) definition, and (2) to include a financial expert on its audit committee, companies would have to sacrifice the diversity of their boards by appointing directors that are not best-suited to the overall needs of their companies. To accommodate these concerns, the SEC expanded those qualifying as "audit committee financial experts" to include directors with experience in analyzing, or evaluating financial statements, as well as to those actively supervising others who perform any of these activities. Thus, beginning March 31, 2003, the SOX definition of a financial expert is closer to the NYSE's and NASDAQ's delineation of a financial expert director. We refer to these directors as non-accounting financial experts because they are not required to directly have accounting experience. See Appendix A for the SOX, NYSE and NASDAQ definitions and rules.

Our primary hypothesis throughout the paper is that audit committee financial expertise mitigates "GAAP" earnings management due to the financial expert having the training and experience to recognize accounting manipulations. The narrow definition of an ACFE in SOX, alongside the SEC's subsequent broadening of that definition and the stock exchanges' expansive delineation of whom an ACFE is, allows us to present several testable hypotheses on what type of background and experience is necessary for the financial expert to be an effective monitor of earnings management. 
We begin our hypothesis section by proposing a negative relation between earnings management and having any type of financial expert on the audit committee. In the alternative form:

H1: There is a significant negative association between abnormal accruals (earnings management) and the presence of an ACFE (accounting or nonaccounting), as disclosed by firms.

Empirical support for $\mathrm{H} 1$ comes from Abbott et al. (2004) and Bédard et al. (2004), who report negative relations between earnings restatements or aggressive earnings management and an ACFE, in which the ACFE has either accounting or nonaccounting expertise. ${ }^{2}$

However, DeFond et al. (2005) provide evidence that accounting and nonaccounting ACFEs may provide different degrees of financial expertise. They find a significantly positive average stock price reaction to the appointment of an accounting ACFE, but no significant stock price reaction to the appointment of a non-accounting ACFE. They argue that these results are consistent with accounting ACFEs, but not nonaccounting ACFEs, having the necessary skills to improve the audit committee's ability to ensure "high-quality financial reporting." DeFond et al.'s (2005) findings suggest that we split financial experts into two classes based on whether they are accounting or nonaccounting experts. We present the following two hypotheses:

$\mathrm{H} 2 \mathrm{a}$ : There is a significant negative association between the presence of an accounting ACFE and abnormal accruals

\footnotetext{
${ }^{2}$ Abbott et al. (2004) define a financial expert as a CPA, investment banker, venture capitalist, CFO, controller, or someone who has held a senior management position (CEO, President, EVP, SVP, VP) with financial responsibilities. Bédard et al. (2004) include CPAs, CFAs, and those with "experience in finance or accounting" as financial experts.
} 
$\mathrm{H} 2 \mathrm{~b}$ : There is a significant negative association between the presence of a nonaccounting ACFE and abnormal accruals.

Several studies support the view that independent directors are better monitors of the financial reporting system (e.g., Carcello and Neal, 2000; 2003; Klein 2002b). The SEC requires firms to disclose whether the ACFE (if there is one) is independent of management (SEC 2002; SEC 2003a). Although Section 301 of SOX requires firms to have independent audit committees, the SEC defines independence in the context of compensation or advisory fees received by the director or by the amount of control that the director has over the firm (SEC 2003c). In contrast, the exchanges have more stringent definitions of director independence, for example limiting personal or family ties with the firm, but they also allow for a limited opt-out at the board's discretion. Thus, the differing definitions of board independence and inclusion requirements could result in non-independent directors serving on the audit committee. This suggests the following hypotheses:

H3a: The association between an accounting ACFE and abnormal accruals is stronger when the expert is independent, where independence is defined to preclude all financial and personal ties between director and firm.

H3b: The association between a non-accounting ACFE and abnormal accruals is stronger when the expert is independent, where independence is defined to preclude all financial and personal ties between director and firm. 


\subsection{Other corporate governance mechanisms, financial expertise, and earnings} management

In December 1999, the NYSE and NASDAQ established new listing requirements on audit committee composition. Both markets require listed firms to have independent audit committees (with some flexibility for a limited opt-out) of at least three members. In November 2003, the NYSE and NASDAQ adopted new listing requirements for board independence, nominating, and compensation committees. Both markets require firms to have majority independent boards, and have placed the functions of board nominations and executive compensation into the hands of the board's independent directors. ${ }^{3}$

The establishment of corporate governance listing standards alongside the fact that SOX does not mandate firms to include a financial expert on its audit committee suggests that Congress and the stock markets view audit committee expertise and other corporate governance mechanisms as substitutes for quality financial reporting.

DeFond et al. (2005) investigate whether the market's reaction to the appointment of an accounting ACFE is complementary or a substitute to the firm's overall governance environment. They find that the positive market reaction to the appointment of an accounting ACFE is greater for firms with strong governance mechanisms than for firms with weak governance mechanisms. DeFond et al. (2005) conclude that audit committee financial expertise and other corporate governance mechanisms are complements, although DeFond and Francis (2005) caution that there is a dearth of research examining the contextual nature of competing governance structures.

Given the tension between the regulators and DeFond et al's (2005) results, we present the following hypothesis in the null:

\footnotetext{
3 The NYSE mandates the establishment of separate, independent nominating and compensation committees. The NASDAQ's rules are more flexible - allowing for these functions to be placed in the hands of non-independent directors alone (see Klein, 2003).
} 
H4: The association between abnormal accruals and a financial expert (variously defined) is not dependent on the overall strength of the firm's corporate governance environment.

\subsection{Real Earnings Management, Other Corporate Governance Mechanisms, and Audit}

\section{Committee Financial Expertise}

Real earnings management is when managers take real economic actions to manage quarterly or annual earnings (or EPS). Graham et al. (2005) find that 80 percent of surveyed CFOs admit they would be willing to decrease discretionary spending on $\mathrm{R} \& \mathrm{D}$, advertising, and maintenance to meet earnings expectations. More than half of the CFOs (55.3 percent) report they would delay a positive net present value investment project to meet earnings expectations. ${ }^{4}$ Empirically, Roychowdhury (2005) finds evidence that managers use $\mathrm{R} \& \mathrm{D}$, advertising, $\mathrm{SG} \& \mathrm{~A}$, and production costs to manage earnings for a sample of firms between 1987-2001. Baber et al. (1991) and Bushee (1998) find similar results for R\&D expenditures alone. Cohen et al. (2005), using Roychowdhury's (2005) methodology, report a rise in real earnings management after the enactment of SOX.

Real earnings management may diminish firm and shareholder value, but it is not illegal. Further, it is not a violation of financial reporting rules, and even if discovered would not result in charges of financial fraud or create cause for an earnings restatement. Thus, we argue that it is beyond the scope of the audit committee's responsibility to filter

\footnotetext{
${ }^{4}$ Graham et al. $(2005 ; 2006)$ also present evidence that CFOs are willing to use "GAAP" earnings management to meet earnings targets. Graham et al. (2005) report that 40.4 percent of CFOs are willing to book revenues early, 27.9 percent would draw down on reserves previously set aside, 21.3 percent would postpone taking an accounting charge, and 20.2 percent are willing to sell investments or assets to recognize the gain this quarter.
} 
out real earnings management. Therefore, we present the following hypothesis in the null:

H5: There is no association between real earnings management and the presence of an audit committee financial expert.

\section{Research Method}

\subsection{Data}

We select a choice-based sample of 350 non-financial, domestic firms from Compact D/SEC with fiscal year ends between July 15, 2003 and December 31, 2003, ${ }^{5}$ and that are traded on the NYSE, Nasdaq's National Market (NNM), and Nasdaq's Small Cap Market (SCM). We select a sample rather than testing the entire population of firms because classifying audit committee members as an accounting ACFE or a nonaccounting ACFE requires reading each audit committee member's biographical sketch in the proxy statement. This process is labor intensive and non-trivial. We eliminate firms that do not have adequate data on Compustat to calculate either abnormal accruals or the necessary control variables, and firms that do not have the corporate governance data needed for us to compute our measure of overall corporate governance quality. We have a final useable sample of 283 firms.

We first examine each firm to determine whether they have disclosed at least one ACFE. Fifty-seven firms state that they do not have an ACFE. ${ }^{6}$ For the remaining 226

\footnotetext{
${ }^{5}$ The SEC's final rule on the disclosure of whether the firm has an ACFE was effective for fiscal years ending on or after July 15, 2003. Our sample is choice-based to ensure an adequate number of firms with no ACFE.

${ }^{6}$ Based on our reading of the proxy statement for these 57 firms, none of the audit committee members appeared to qualify as an accounting ACFE. Although some of the audit committee members at these firms had similar backgrounds to non-accounting ACFEs at other firms, these individuals were not designated as an ACFE by the firms where they sat on the audit committee.
} 
firms, we examine the background of each disclosed ACFE to determine if they had previous experience in accounting. Consistent with the original definition of SOX, we define an accounting ACFE to be any ACFE with current or previous experience as a CPA, CFO, controller, treasurer, or vice president-finance. All other disclosed ACFEs are considered non-accounting ACFEs. An examination of our sample indicates that 141 firms have at least one accounting ACFE, and 85 have at least one non-accounting ACFE but no accounting ACFE.

Table 1 presents details on the job backgrounds of the accounting ACFEs (ACC_ACFE) and the non-accounting ACFEs (NONACC_ACFE), including information on when these individuals joined the audit committee. Although only 226 firms have an ACFE, there are 317 individual ACFEs in our sample because some firms have disclosed more than one ACFE. As Panel A shows, approximately two-thirds $(103 / 160)$ of the ACC_ACFEs serve, or have served, as a chief financial officer (CFO), and almost 30 percent (45/160) of the ACC_ACFEs who are not CFOs are CPAs. Over 80 percent $(129 / 157)$ of the NONACC_ACFEs hold (held) non-financial positions as senior business executives (e.g., CEO, President, Chairman of the Board, Chief Operating Officer, Vice President). The remaining NONACC_ACFEs include investment bankers, venture capitalists, consultants, private investors, attorneys, and academics.

We also gathered data on when the ACFEs joined the audit committee. Forty-six percent (31 percent) of the ACC_ACFEs (NONACC_ACFEs), respectively, joined the audit committee within the past two years. This suggests that SOX' financial expert requirement has led to substantial changes on corporate audit committees, presumably consistent with the objective of the law. Moreover, accounting experts are approximately 50 percent more likely to have been added to the audit committee than are non- 
accounting experts. This, too, is consistent with the intent of the law. However, it remains an empirical question as to whether ACC_ACFEs are more effective in monitoring the financial reporting process than are NONACC_ACFEs, and an empirical question as to whether the benefits of effective monitoring can be achieved through mechanisms other than the presence of an ACFE.

\subsection{Abnormal accruals}

Previous literature has examined abnormal accruals using many different models. Dechow et al. (1995) conduct tests to determine which model is most effective at separating abnormal accruals from "normal" accruals. They conclude that the Modified Jones Model is best at identifying abnormal accruals. Based on these findings we employ the Modified Jones Model to estimate abnormal accruals for each sample company.

We begin by estimating the expected accruals for each firm $i$ in industry $j$, using ordinary least squares regression. The model is:

(1) $T A_{i j}=\alpha_{i j}+\beta_{1 i j}\left(1 / \operatorname{lag} 1\right.$ Assets $\left._{i j}\right)+\beta_{2 i j}\left(\Delta R E V_{i j}-\Delta A R_{i j}\right)+\beta_{3 i j} P P E_{i j}+\varepsilon_{i j}$

where $\mathrm{TA}_{\mathrm{ij}}$ is total accruals for firm $i$ in industry $j$ [Compustat item \#18 - (Compustat item $\# 308$ - Compustat item \#124)], $\triangle \mathrm{REV}_{\mathrm{ij}}$ is the one year change in net revenues [Compustat item \#12], $\Delta \mathrm{AR}_{\mathrm{ij}}$ is the one year change in accounts receivable [Compustat item \#2], and $\mathrm{PPE}_{\mathrm{ij}}$ is gross property, plant, and equipment [Compustat item \#7]. All variables are scaled by lagged total assets. The changes in revenues, receivables, and PPE, calculated as the difference between years $\mathrm{t}$ and $\mathrm{t}-1$, control for the expected components of total accruals.

Industry-specific expected accruals are calculated using all firms on Compustat with the same three, two, or one-digit SIC code, conditional on having at least 20 firms 
with usable data in each SIC group. ${ }^{7}$ Abnormal accruals (AAC) are the prediction errors from equation (1). More specifically, we calculate abnormal accruals as the difference between the total accruals for each firm less the expected industry specific accruals for that firm based on the estimated coefficients from equation (1):

(2) $A A C_{i}=T A_{i}-\left(\hat{\alpha}_{i}+\hat{\beta}_{1 i}\left(1 / \operatorname{lag} 1 A s s e t s_{i}\right)+\hat{\beta}_{2 i}\left[\Delta R E V_{i}-\Delta A R_{i}\right]+\hat{\beta}_{3 i} P P E_{i}\right)$.

Consistent with Kothari et al. (2005), we performance-adjust the abnormal accruals based on each sample firm's prior year return-on-assets (ROA). This procedure controls for "normal" earnings management given the sample firm's level of performance. Specifically, we rank firms within each industry group into deciles based on their prior year's return-on-assets (ROA) and calculate the median abnormal accruals for each industry group ROA decile, where the median ROA value excludes the particular sample firm. We then calculate the performance-adjusted abnormal accrual for each sample firm by taking the difference between the sample firm's abnormal accruals and the median abnormal accruals from the appropriate industry group ROA decile.

Since our sample is a relatively small percentage of all public companies - due to the difficulty in hand collecting proxy data - there is always some risk that our results are sample specific. In particular, we are concerned that our sample is stratified in terms of earnings growth, risk, or size, parameters that have been shown to produce biased measures of earnings management (Kothari et al., 2005). To address this concern, we compare our sample firms with the entire Compustat population on four metrics: sales growth, book-to-market ratio (M/B), firm size, and operating cash flow (OCF) (see Kothari et al., 2005). We partition the Compustat universe into quartiles for each of these four metrics. If our sample mirrors the Compustat population, we would expect

\footnotetext{
${ }^{7}$ To control for the effect of outliers, total accruals are winsorized at the $1^{\text {st }}$ and $99^{\text {th }}$ percentiles prior to the estimation of normal accruals.
} 
approximately half of our sample observations to fall within the first and fourth quartiles

for each of these metrics. The percentage of our sample that falls within the first and fourth quartiles for sales growth, M/B ratio, firm size, and OCF is 46 percent, 47 percent, 48 percent, and 47 percent, respectively. These results suggest that our sample is similar to the overall Compustat population, and suggest that our results are not driven by the unique properties of our sample.

\subsection{Model}

We initially test the relation between abnormal accruals and the existence of an ACFE (regardless of type) using the following regression model:

$$
\begin{aligned}
\text { LN_ABS_PAC }= & \mathrm{b}_{0}+\mathrm{b}_{1} \mathrm{ACFE}+\mathrm{b}_{2} \text { STRONGGOV }+\mathrm{b}_{3} \mathrm{ACFE} * \text { STRONGGOV }+ \\
& \mathrm{b}_{4} \mathrm{SIZE}+\mathrm{b}_{5} \mathrm{M} / \mathrm{B}+\mathrm{b}_{6} \text { DISTRESS }+\mathrm{b}_{7} \mathrm{OCF}+\mathrm{b}_{8} \text { LEVERAGE }+ \\
& \mathrm{b}_{9} \mathrm{BIG} 4+\varepsilon
\end{aligned}
$$

We define the dependent, test, and control variables as follows:

$\begin{array}{ll}\text { LN_ABS_PAC }= & \begin{array}{l}\text { natural } \log \text { of the absolute value of the discretionary accrual } \\ \text { measure adjusted for performance; }\end{array} \\ \text { ACFE } & 1 \text { if firm has at least one ACFE, else } 0 ; \\ \text { STRONGGOV }= & 1 \text { if the firm has strong overall corporate governance based on a } \\ & \text { six-factor measure, else } 0 \text { (see definition below); } \\ = & \text { natural log of market value of equity; } \\ = & \text { market value of the total firm divided by the book value of assets, } \\ \text { SIZE } & \text { measured at the beginning of the fiscal year; } \\ \text { M/B }= & \text { Zmijewski's (1984) financial condition index; } \\ \text { DISTRESS } & \text { cash flow from operations scaled by the beginning of the year } \\ \text { OCF } & \text { total assets; } \\ \text { LEVERAGE } & \text { total debt divided by total assets; } \\ \text { BIG4 } & =1 \text { if the firm engaged one of the largest four audit firms, else } 0 .\end{array}$

\footnotetext{
${ }^{8}$ We use the absolute value of the performance-adjusted abnormal accruals (ABS_PAC) as a proxy for the combined effect of both income increasing and income decreasing abnormal accruals (Warfield et al., 1995; Francis et al., 1999; DeFond and Park, 1997; Healy, 1985). We use the natural log of the absolute value of performance-adjusted discretionary accruals because the regression residuals are not normally distributed if the ABS_PAC is used. We compute the natural log of ABS_PAC to address this issue of non-normality.
} 
The primary variables of interest in this analysis are ACFE (H1) and the interaction between ACFE and STRONGGOV (H4). We expect a negative relation between an ACFE and earnings management, indicating that firms with at least one ACFE have performance-adjusted discretionary accruals whose absolute value is less than firms with no ACFE. We also expect a negative relation between STRONGGOV, a strong corporate governance environment, and abnormal accruals. The interactive term ACFE*STRONGGOV tests whether the relation between an ACFE and earnings management is dependent on the strength of the firm's overall corporate governance environment. This interaction variable essentially tests whether ACFEs and other corporate governance mechanisms are substitutes or complements, as it relates to earnings management.

Consistent with DeFond et al. (2005), we create a composite measure of overall corporate governance quality using six equally weighted governance characteristics. The six governance characteristics and their measurements are (one always equals stronger governance):

Board size

Board independence

Audit committee size
$=1$ if the firm's board size is less than the sample median, else 0 ;

$=1$ if 60 percent or more of the firm's directors are independent, else 0 ;

$=1$ if the proportion of the firm's audit committee size to its board size is greater than the sample median, else 0 ;

Audit committee independence $=1$ if the audit committee is 100 percent independent, else 0 ;

Shareholders' rights $\quad=1$ if the firm's Corporate Governance Quotient (per Institutional Shareholder Services) is greater than the sample median, else $0{ }^{9}$

\footnotetext{
${ }^{9}$ DeFond et al. (2005) use the G index developed by Gompers et al. (2003) to measure shareholder rights. They obtain the $G$ index from the Investor Responsibility Research Center (IRRC) database. The G index is skewed toward larger companies; only 135 of the companies in our sample had a $\mathrm{G}$ index available on the IRRC database. Therefore, we use Institutional Shareholder Services' (ISS) Corporate Governance Quotient (CGQ), a comparable index to the G index, to measure shareholder rights. The G index has 24 factors and includes measurements of whether firms have staggered board terms, allow cumulative voting,
} 
Institutional ownership

$=1$ if the firm's percentage of institutional ownership is greater than the sample median, else 0 .

We define a firm as having strong corporate governance if the summation of the individual governance measures for a particular firm equals or exceeds the sample median for this measure. ${ }^{10}$ In addition to DeFond et al. (2005), other researchers have found the above factors to be associated with good corporate governance. Jensen (1993) argues that smaller boards are more effective monitors and Yermack (1996) finds that smaller boards are associated with higher firm value. A number of prior studies find that better corporate governance is associated with board independence (e.g., see Weisbach, 1988; Dechow et al., 1996; Core et al., 1999; and Klein, 2002a), with audit committee independence (e.g., see Carcello and Neal, 2000; 2003; Klein, 2002a; Abbott et al., 2004; Anderson et al., 2004; and Bédard et al., 2004), and with audit committee size (Abbott et al., 2004; Anderson et al.. 2004). LaPorta et al. (2002) find higher firm valuation in countries with better protection of shareholders' rights. Finally, studies find that institutional owners play an important role in firm governance through their monitoring of management (e.g., see Shleifer and Vishny, 1986; Coffee, 1991; and Bhojraj and Sengupta, 2003).

In addition to the variables of interest, we control for several factors suggested by previous literature as being associated with audit committee characteristics and/or abnormal accruals. Klein (2002a) and Warfield et al. (1995) find that abnormal accruals

and have poison pills (DeFond et al. 2005). The CGQ has 61 factors and includes measurements of charter and bylaw provisions, anti-takeover provisions, executive and director compensation, and ownership. A large majority of our original sample has an available CGQ. Thirty-six observations from our initial sample of 350 are excluded because of a missing CGQ.

${ }^{10}$ The sample median for the summation of the individual governance measures is three. The sample medians for the individual governance characteristics are: board size (seven), board independence (0.67), the proportion of audit committee size to board size (0.43), audit committee independence (100 percent), shareholders' rights (47), and institutional ownership (0.48). 
are positively associated with a firm's market-to-book ratio and negatively associated with size. Firm leverage, cash flow from operations, and the presence of a Big 4 auditor have been found to be negatively related to abnormal accruals (Warfield et al. 1995; Dechow et al. 1996; Becker et al. 1998; Francis et al. 1999; Bartov et al. 2000; Frankel et al. 2002). Finally, Reynolds and Francis (2000) note that the Modified Jones Model may overestimate accruals for poorly performing firms. Thus we include DISTRESS, a measure of the firm's financial condition, in the model to control for these concerns. Consistent with Reynolds and Francis, we expect a positive relation between a firm's financial distress and abnormal accruals.

We then extend this initial model to test whether the type of ACFE matters - that is, we create separate dummy variables for whether an accounting (H2a) or a nonaccounting (H2b) ACFE is on the audit committee. We expect the coefficient on ACC_ACFE to be negative. And, if non-accounting ACFEs are similar to accounting ACFEs - essentially what is implied by the SEC's Final Rule - than we would expect the coefficient for NONACC_ACFE to be negative as well. However, given the lack of significant stock price reaction upon the appointment of a non-accounting ACFE to the board (DeFond et al. 2005), the relation between abnormal accruals and NONACC_ACFE may be weaker than the relation between abnormal accruals and ACC_ACFE.

Finally, we extend our base model by examining the associations between earnings management and ACC_ACFE and NONACC_ACFE, limiting our consideration to only those financial experts that are independent (H3a and H3b). The SEC requires the disclosure of whether the firm's ACFE is independent (SEC 2003b), suggesting that nonindependent ACFEs may be less effective monitors of the financial reporting process. 


\section{Results}

\subsection{Descriptive statistics}

Table 2 presents descriptive statistics in aggregate and by whether the firm has at least one accounting ACFE, a non-accounting ACFE but no accounting ACFE, or if the firm discloses not having an ACFE. As expected, firms with at least one accounting ACFE have lower absolute values of abnormal accruals than firms with no ACFE $(\mathrm{p}<$ 0.10). However, the absolute value of abnormal accruals is not significantly different between firms with an accounting ACFE and a non-accounting ACFE; nor is there a significant difference between firms with at least one non-accounting ACFE and firms with no ACFE. Interestingly, firms with a non-accounting ACFE are larger than firms with an accounting financial expert $(\mathrm{p}<0.10)$. In addition, firms with no ACFE are less likely to engage a Big 4 audit firm than firms with an accounting ACFE $(\mathrm{p}<0.10)$ or with a non-accounting ACFE $(\mathrm{p}<0.01)$.

Table 3 presents the correlations ${ }^{11}$ among the independent variables. All but four of the correlations fall between $+/-0.35$, which suggests that the variables included in our model measure distinct features. The highest correlation is 0.76 , which reflects a significant positive relation between DISTRESS and LEVERAGE. This relation was not unexpected given that a key component of the distress measure is the debt to assets ratio. The only other control variables with correlations greater than $+/-0.35$ are those between the market to book ratio and operating cash flow (-0.64), and between BIG4 and SIZE (0.51). Given these high correlations, we calculate variance inflation factors for all

\footnotetext{
${ }^{11}$ We present Pearson correlations for continuous variables and Spearman correlations for dichotomous variables.
} 
models and find that the highest VIF is 7.01 , which is within acceptable limits. ${ }^{12}$ Thus, multicollinearity does not appear to be a problem in any of our models.

\subsection{Multivariate results}

\subsubsection{Earnings Management and Financial Expertise}

Table 4 contains the results of the regression model used to test the relation between abnormal accruals and the presence of an ACFE. The overall model is highly significant $(\mathrm{p}<0.01)$, and the model's pseudo- $\mathrm{R}^{2}$ is nine percent. Consistent with our expectation in $\mathrm{H} 1$, the coefficient on ACFE is significantly negative $(\mathrm{p}<0.05)$, indicating that firms with at least one ACFE have lower levels of abnormal accruals than firms with no ACFE. We also find that firms with a stronger overall corporate governance environment (STRONGGOV) have a lower level of abnormal accruals $(p<0.05)$. The interactive term ACFE*STRONGGOV tests whether a financial expert and other governance mechanisms are complements or substitutes. The significant positive coefficient on the interactive term $(\mathrm{p}<0.10)$ indicates that the relation between abnormal accruals and an ACFE is conditional on the strength of the firm's overall corporate governance environment, and is consistent with a substitution effect between ACFE and STRONGGOV. To demonstrate these associations more clearly, we test whether $\left(b_{1}+\right.$ $b_{3}$ ), the sum of the coefficients on ACFE and ACFE*STRONGGOV, is significantly different from zero. We find that $\left(b_{1}+b_{3}\right)$ is not significantly different from zero $(F=$ $0.22, \mathrm{p}>0.10)$, indicating that the negative association between earnings management and an ACFE only applies for those firms with weak alternate corporate governance

\footnotetext{
${ }^{12}$ Gujuarati $(1995,339)$ suggests that as long as the VIF is less than 10.0 multicollinearity is unlikely to be a problem.
} 
mechanisms. These results suggest that a firm's overall corporate governance environment can substitute for the presence of an ACFE and vice versa.

The coefficients on the control variables are generally consistent with previous literature. Abnormal accruals are positively related to the market-to-book ratio $(\mathrm{p}<0.05)$ and to financial distress $(\mathrm{p}<0.05)$, and negatively related to firm size $(\mathrm{p}<0.05)$, firm leverage $(\mathrm{p}<0.10)$, and whether or not the firm engaged a Big 4 auditor $(\mathrm{p}<0.10)$. There is no significant relation between abnormal accruals and operating cash flows.

\subsubsection{Earnings Management and Type of Audit Committee Financial Expert}

Although we find a significantly negative relation between earnings management and the presence of an ACFE, that negative association could be driven by accounting ACFEs, by non-accounting ACFEs, or by both groups. In Table 5, we examine the separate relations between accounting financial experts (ACC_ACFE) and nonaccounting financial experts (NONACC_ACFE) and earnings management.

We find a significantly negative coefficient between an ACC_ACFE and earnings management $(\mathrm{p}<0.05)$, supporting $\mathrm{H} 2 \mathrm{a}$ which proposes a negative association between an accounting financial expert and earnings management. In contrast, the coefficient on NONACC_ACFE is insignificantly different from zero, indicating no systematic relation between earnings management and non-accounting financial experts $(\mathrm{H} 2 \mathrm{~b})$. Thus, similar to DeFond et al.'s (2005) price reaction data, we find differences between accounting and non-accounting financial experts.

The coefficient on STRONGGOV is significantly negative $(\mathrm{p}<0.05)$, suggesting that alternative corporate governance mechanisms still play a role in mitigating earnings management. The positive coefficient on the interactive term ACC_ACFE* 
STRONGGOV suggests a trade-off between having an accounting financial expert on the audit committee and a strong corporate governance environment $(p<0.10) .{ }^{13}$ We note that the coefficients and the significance levels of the control variables are generally consistent with Table 4. In addition, the insignificant coefficient on the interactive term NONACC_ACFE*STRONGGOV is consistent with there being little to no impact of including a non-accounting financial expert on the audit committee.

In summary, our empirical results in Table 5 support the view that financial experts with accounting backgrounds and experiences are better able to monitor earnings management than financial experts without accounting backgrounds. The results also support the hypothesis that accounting financial experts and other strong corporate governance mechanisms are substitutes for each other.

\subsubsection{Further Analyses of Backgrounds of Non-Accounting Audit Committee Financial Experts}

While the accounting financial experts' backgrounds are fairly similar, that is, they all have hands on experience with preparing financial statements, the backgrounds of the non-accounting financial experts are more diverse. However, a closer examination of the non-accounting ACFEs reveals that we can essentially bifurcate our sample of nonaccounting ACFEs into two groups: (1) senior business executives and (2) all other nonaccounting ACFEs. We define EXEC as an indicator equal to one if the non-accounting ACFE is a current or retired senior manager in another firm, that is, a CEO, Chairman of the Board, President, Chief Operating Officer, or Vice President. OTHER is an indicator

\footnotetext{
13 An insignificantly positive "coefficient" on $\left(b_{1}+b_{4}\right)$, supports this finding $(p=0.46)$.
} 
variable equal to one if the non-accounting financial expert is not a current or retired senior manager in another firm. Non-accounting financial experts who are not a current or retired senior manager include investment bankers, venture capitalists, private investors, consultants, attorneys, academics, retirees, principals, and directors. ${ }^{14}$

In devising these two categories, we note that the SEC explicitly states that investment bankers and venture capitalists are likely to qualify as ACFEs (SEC, 2003b). Thus, they endorse the notion that users of financial statements qualify as financial experts. Conversely, the NASDAQ explicitly includes chief executive officers or other senior officers with financial oversight responsibilities within its description of who qualifies as a financial expert (NASDAQ listing standards). We recognize that our two classifications are based on our perceptions of who fits into each category, and that these perceptions may add noise to our two independent variables. Based on our findings in the last section that NONACC_ACFE is not systematically related to earnings management, we make no predictions about whether one or both classifications of NONACC_ACFE will be associated with less earnings management.

Table 6 presents the results of our analysis where the NONACC_ACFE variable is replaced by EXEC and OTHER. The overall model is highly significant $(\mathrm{p}<0.01)$ and the model's pseudo- $\mathrm{R}^{2}$ is nine percent. We continue to find a significantly negative relation between ACC_ACFE and earnings management for firms with weak corporate governance $(\mathrm{p}<0.05)$. However, unlike the insignificantly negative coefficient on NONACC_ACFE that we report in Table 5, Table 6 shows a significantly negative relation between non-accounting financial experts who are not senior business executives (OTHER) and earnings management $(\mathrm{p}<0.10)$, but no significant relation between those

\footnotetext{
${ }^{14}$ No one type of background predominates among non-accounting ACFEs who are not current or retired senior managers. For example, there are five venture capitalists, four consultants, four directors, three private investors, three attorneys, and three principals.
} 
non-accounting ACFEs who have a background as a senior business executive and earnings management. We also find insignificant coefficients on the interactive terms EXEC*STRONGGOV and OTHER*STRONGGOV. ${ }^{15}$

The results in Table 6 weakly suggest that firms can achieve the benefits of improved monitoring of the financial reporting process by adding a non-accounting financial expert to the audit committee, as long as this individual is not a senior business executive. One possible explanation for this result is that senior business executives on audit committees may be less vigilant in monitoring the financial reporting process, either because of the demands of their full-time positions or because they expect management to properly have some discretion in managing the accrual process. This result is clearly preliminary and calls for further study with larger sample sizes.

\subsubsection{Director Independence and the Background of the Audit Committee Financial Expert}

Our analyses up to this point have examined the association between earnings management and the presence of an audit committee financial expert regardless of whether the financial expert is independent. However, Klein (2002a) finds a negative relation between earnings management and the percentage of independent directors on the audit committee, suggesting that a financial expert's effectiveness in monitoring the financial reporting process may differ depending on whether or not the expert is independent.

We define an independent director as one who (1) does not work for the company beyond being a director and (2) does not have any other financial or personal relationship

${ }^{15}$ A joint test of the OTHER and OTHER*STRONGGOV coefficients $\left(b_{3}+b_{7}\right)$ is not significantly different from zero $(p=0.99)$ indicating that other non-accounting financial experts are not effective in reducing earnings management for firms with strong corporate governance. 
with the firm. Using this definition, we classify 130 ACC_ACFEs as independent and 11 as non-independent of management. Similarly, we find that 73 EXECs and 12 OTHERs are independent, whereas four EXECs and one OTHER are not independent of management.

We examine the associations between independent ACC_ACFEs, independent EXECs, and independent OTHERs and earnings management. We create three dummy variables, ACC_ACFE_IND, EXEC_IND, and OTHER_IND each equal to one respectively for independent directors with that background, and zero otherwise. ${ }^{16}$

Table 7 presents the empirical results. Consistent with our expectations in H3a, independent ACFEs appear to be more effective than non-independent ACFEs. First, there is a significantly negative relation between earnings management and an ACC_ACFE_IND $(\mathrm{p}<0.01)$. More telling, however, we find that the negative relation between earnings management and an $\mathrm{ACC}_{-} \mathrm{ACFE}$ is stronger when the ACC_ACFE is independent. That is, we test whether the coefficient on the ACC_ACFE_IND variable from Table 7 is significantly different from the coefficient on the ACC_ACFE variable from Table 6. We find a significant difference between coefficients (chi-square $=2.86 ; \mathrm{p}$ $<0.05)$, supporting the hypothesis that director independence and an accounting background together deter earnings management more than just an accounting background alone.

Similarly, we find a significantly negative relation between earnings management and OTHER_IND $(\mathrm{p}<0.05)$. When we compare the coefficient on OTHER_IND in Table 7 with the coefficient on OTHER in Table 6, we reject the hypothesis that they are

\footnotetext{
${ }^{16} \mathrm{We}$ also do the analysis without disaggregating NONACC_ACFE into EXEC and OTHER, creating a dummy variable equal to one if any non-accounting ACFE is independent and zero otherwise. Our analysis with this variable is similar to what we report with the EXEC_IND and OTHER_IND variables in this section and therefore do not include it.
} 
equal, and find, instead that OTHER_IND is significantly less than OTHER (chi-square $=$ 2.52; $\mathrm{p}<0.10)$. Thus independence matters as well for non-accounting ACFEs who are not senior business executives.

In contrast, we find that the coefficient on EXEC_IND to be insignificantly different from zero. This finding corroborates our inference in the last section that senior executives of other companies, even those who are independent of managers, appear to be less effective monitors of the firm's financial reporting system.

In Table 7, STRONGGOV remains significantly negative, consistent with the hypothesis that a strong corporate governance environment is negatively associated with earnings management. Moreover, the significant positive coefficient on ACC_ACFE_IND*STRONGGOV $(\mathrm{p}<0.10)$ indicates that the positive monitoring benefits offered by independent accounting experts differ depending on the strength of the firm's corporate governance environment. We find no such trade-off between nonaccounting ACFEs who are not senior business executives and a strong corporate governance environment. ${ }^{17}$

Our combined results from Tables 5-7 indicate that some, but not all, ACFEs reduce earnings management. Specifically, accounting financial experts and nonaccounting ACFEs who are not senior business executives reduce earnings management, especially if they are independent, while senior business executives do not. These results suggest that, within large boundaries, firms should be provided with considerable flexibility in devising the corporate governance oversight structures that best fits the needs of the particular firm.

\footnotetext{
${ }^{17}$ A joint test of the OTHER IND and OTHER IND*STRONGGOV coefficients $\left(b_{3}+b_{7}\right)$ is not significantly different from zero $(\mathrm{p}=0.83)$ indicating that other, independent non-accounting financial experts are not effective in reducing earnings management for firms with strong corporate governance.
} 


\section{Additional Analyses: When the Accounting Audit Committee Financial Expert}

\section{Joined the Audit Committee}

The descriptive statistics presented in Table 1 indicate that 46 percent of the accounting financial experts joined the audit committee within the past two years. It is possible that accounting financial experts joining the audit committee post-Enron and post-SOX might be more effective in overseeing the financial reporting process. We divide our ACC_ACFE variable into two variables based on when the accounting financial expert joined the audit committee - one that measures whether the only ACC_ACFE joined the committee within the past two years, the other that measures whether one or more ACC_ACFEs were on the audit committee pre-2002. In results not tabled, we find significant negative relations between earnings management and both of the ACC_ACFE variables $(\mathrm{p}<0.05)$ for firms with weak corporate governance. These results suggest that the effectiveness of ACC_ACFEs is not limited to only those experts being added to the audit committee as a result of SOX.

\section{Financial Expertise, Operating Decisions, and Real Earnings Management}

Management can manage earnings either through accounting estimates and judgments, or through "real" actions that serve to accelerate or delay the recognition of discretionary expenditures (e.g., advertising, R\&D, training, travel, etc.) (see Schipper 1989). Management can also affect earnings through its management of inventory levels. In $\mathrm{H} 5$, we posit that an ACFE has little effect on real earnings management, because the management of discretionary expenditures and production costs is generally not fraudulent and would be well within the accepted province of management's discretion. 
Roychowdhury (2005) and Cohen et al. (2005) use a firm's abnormal level of discretionary expenditures and abnormal level of production costs (using a similar technique to the modified-Jones model) as metrics of real earnings management. Following these papers, we estimate the following cross-sectional regressions for each three, two, or one-digit SIC code, conditional on having at least 20 firms with usable data in each SIC group, in order to generate the normal (predicted) levels of discretionary expenses and production costs:

(3) $\operatorname{DiscExp}_{\mathrm{i}} /$ Assets $_{\mathrm{it}-1}=\mathrm{a}_{1}\left(1 /\right.$ Assets $\left._{\mathrm{i}, \mathrm{t}-1}\right)+\mathrm{a}_{2}$ Sales $_{\mathrm{it}} /$ Assets $_{\mathrm{i}, \mathrm{t}-1}+\varepsilon_{\mathrm{it}}$

(4) $\operatorname{Prod}_{\mathrm{it}} / \operatorname{Assets}_{\mathrm{i}, \mathrm{t}-1}=\mathrm{b}_{1}\left(1 /\right.$ Assets $\left._{\mathrm{i}, \mathrm{t}-1}\right)+\mathrm{b}_{2}$ Sales $_{\mathrm{it}} /$ Assets $_{\mathrm{i}, \mathrm{t}-1}+\mathrm{b}_{3} \Delta$ Sales $_{\mathrm{it}} /$ Assets $_{\mathrm{i}, \mathrm{t}-1}+$ $\mathrm{b}_{4} \Delta$ Sales $_{\mathrm{i}, \mathrm{t}-1} /$ Assets $_{\mathrm{i}, \mathrm{t}-1}+\varepsilon_{\mathrm{it}}$

We define discretionary expenditures (DiscExp) as the sum of the firm's advertising expense (Compustat data item \#45), R\&D expense (data item \#46), and selling, general, and administrative expense (data item \#189). Abnormal discretionary expenditures for firm $i$ is calculated as the difference between its actual discretionary expenditures and its normal level of discretionary expenditures. We define production costs (Prod) as the sum of the firm's cost of goods sold (data item \#41) and change in inventories (data item \#3). Abnormal production costs for firm $\mathrm{i}$ is the difference between its actual production costs and normal production costs. Our control variables are drawn from Cohen et al. (2005). We control for the natural $\log$ of the market value of equity, cash flow from operations, audit firm type, and the absolute value of performance-adjusted discretionary accruals per the Modified Jones model. In addition, we include discretionary expenditures as an explanatory variable in the production cost regression model, and production cost as an explanatory variable in the discretionary expenditure model.

Table 8 presents the results of these models. In the production cost regression (Panel A), we fail to find significant associations between abnormal production costs and 
an ACC_ACFE or NONACC_ACFE. However, in the discretionary expenditures regression (Panel B), we find a significantly positive relation between an accounting ACFE and abnormal discretionary expenditures $(\mathrm{p}<0.05)$ for those firms with weak corporate governance. In addition, we fail to find a significant relation between the strength of the firm's overall corporate governance environment and abnormal production costs, but we find a significantly positive relation between overall corporate governance strength, STRONGGOV, and abnormal discretionary expenditures.

These results, when coupled with our earlier findings, suggest that an accounting ACFE can mitigate earnings management via discretionary accruals for firms with a weak corporate governance environment, but that managers in these firms react by increasing real earnings management (i.e., by reducing discretionary expenditures). Moreover, a strong overall corporate governance environment reduces discretionary accruals, but here too managers appear to respond by increasing real earnings management. These results suggest that although ACFEs and other corporate governance mechanisms are effective in reducing earnings management achieved through accounting maneuvers, neither monitoring mechanism appears to have any effect in reducing the management of earnings through real operating decisions. Although the focus of SOX and the SEC has been on non-GAAP earnings management, Graham et al. (2005) find that CFOs are willing to sacrifice long-term firm value in order to smooth earnings. As suggested by these authors, boards and audit committees may want to exercise greater vigilance in overseeing wealth destroying actions by senior management designed to smooth earnings. 


\section{Summary, Limitations, and Conclusions}

We examine the association between earnings management and various types of ACFEs in the first year that firms must publicly disclose the identity of their financial experts. We also examine whether the strength of the firm's overall corporate governance environment substitutes for, or complements, the presence of an ACFE. We find that an accounting ACFE consistently is associated with less earnings management for firms with weaker overall corporate governance, and that accounting ACFEs who are independent are more effective than accounting ACFEs who are not independent. We fail to find a similar relation between earnings management and the presence of a nonaccounting ACFE, unless the non-accounting ACFE is not a current or former senior business executive and, as was the case with an accounting ACFE, this result is stronger if the non-accounting, non-senior business executive is independent. Moreover, we find that earnings management is not reduced by the presence of an ACFE if the firm has a stronger overall corporate governance environment. These results indicate that the firm's overall governance environment and audit committee financial experts act as substitutes for one another. Finally, we fail to find any relation between ACFEs and management of abnormal production costs, but we find a positive relation between an accounting ACFE and abnormal discretionary expenditures. These findings suggests that although accounting ACFEs may be effective in constraining the management of accounting accruals, management reacts by engaging in real earnings management activities by altering the level of discretionary expenditures.

Our paper is subject to a number of limitations. First, our categorization of audit committee members as an ACFE is dependent on firms' public disclosures. Although firms are required to identify at least one ACFE if such an individual exists, the quality 
and transparency of this disclosure is likely to vary across firms. Second, our measure of earnings management, performance-adjusted abnormal accruals, is only as good as the underlying measure. However, we have computed this measure in accordance with the extant literature. Finally, our results are based on only one year of data. Our sample is representative of the overall Compustat population in that year; and given the lack of empirical data on the relation between various types of ACFEs and earnings management, especially post-SOX, we provide initial empirical data on an important public policy issue.

Our results suggest that there are multiple ways of achieving effective oversight of the financial reporting process, at least as measured by abnormal accruals. A stronger overall system of corporate governance seems to negate the need for an ACFE. And an accounting ACFE and, to a lesser extent, certain types of non-accounting ACFEs, seem to act as effective substitutes for a weaker overall system of corporate governance. These results suggest that regulators should fashion regulations that allow corporate boards and management to design the particular mix of monitoring mechanisms that are optimal for the firm. In the area of audit committee financial experts, the U.S. Congress and the SEC largely permit this flexibility - an audit committee financial expert is not required (only disclosure is required), a financial expert has been defined broadly to include both an accounting and a non-accounting financial expert, and the expert does not have to be independent (although his or her independence status must be disclosed). The results of our study suggest that this flexibility is optimal. 


\section{Appendix: Rules on Defining Financial Expertise}

\section{SEC Rule on the Definition of Financial Expertise}

"Disclosure Required by Sections 406 and 407 of the Sarbanes-Oxley Act of 2002"

SEC Release Nos. 33-8177; 34-47235; File No. S7-40-02 dated January 23, 2003

The final rules define an audit committee financial expert as a person who has the following attributes:

- An understanding of generally accepted accounting principles and financial statements;

- The ability to assess the general application of such principles in connection with the accounting for estimates, accruals and reserves;

- Experience preparing, auditing, analyzing or evaluating financial statements that present a breadth and level of complexity of accounting issues that are generally comparable to the breadth and complexity of issues that can reasonably be expected to be raised by the registrant's financial statements, or experience actively supervising one or more persons engaged in such activities;

- An understanding of internal controls and procedures for financial reporting; and

- An understanding of audit committee functions.

Under the final rules, a person must have acquired such attributes through any one or more of the following:

(1) Education and experience as a principal financial officer, principal accounting officer, controller, public accountant or auditor or experience in one or more positions that involve the performance of similar functions; 
(2) Experience actively supervising a principal financial officer, principal accounting officer, controller, public accountant, auditor or person performing similar functions;

(3) Experience overseeing or assessing the performance of companies or public accountants with respect to the preparation, auditing or evaluation of financial statements; or

(4) Other relevant experience.

\section{NYSE Listing Requirement on Definition of Financial Expertise (Literacy)}

"NYSE Listing Manual" Section 303A.07 Audit Committee Additional Requirements

(a) The audit committee must have a minimum of three members.

Commentary: Each member of the audit committee must be financially literate, as such qualification is interpreted by the listed company's board in its business judgment, or must become financially literate within a reasonable period of time after his or her appointment to the audit committee. In addition, at least one member of the audit committee must have accounting or related financial management expertise, as the listed company's board inteprets such qualification in its business judgment. While the Exchange does not require that a listed company's audit committee include a person who satisfies the definition of audit committee financial expert set out in Item 401(h) of Regulation S-K, a board may presume that such a person has accounting or related financial management expertise.

\section{Nasdaq Listing Requirement on Definition of Financial Expertise (Sophistication)}

"NASD Manual” Section 4350(d)(2) Audit Committee Composition 
(A) Each issuer must have, and certify that it has and will continue to have, an audit committee of at least three members, each of whom must: (i) be independent as defined under Rule 4200(a)(15); (ii) meet the criteria for independence set forth in Rule 10A3(b)(1) under the Act (subject to the exemptions provided in Rule 10A-3(c)); not have participated in the preparation of the financial statements of the company or any current subsidiary of the company at any time during the past three years; and (iv) be able to read and understand fundamental financial statements, including a company's balance sheet, income statement, and cash flow statement. Additionally, each issuer must certify that it has, and will continue to have, at least one member of the audit committee who has past employment experience in finance or accounting, requisite professional certification in accounting, or any other comparable experience or background which results in the individual's financial sophistication, including being or having been a chief executive officer, chief financial officer or other senior officer with financial oversight responsibilities. 
Table 1

Job Backgrounds and Tenure of Audit Committee Financial Experts

Panel A - ACFE Background ${ }^{a}$

\begin{tabular}{|c|c|c|c|c|c|c|}
\hline \multirow[b]{2}{*}{$\begin{array}{c}\text { Exchange } \\
{\text { (No. of Co. })^{b}}^{b}\end{array}$} & \multicolumn{3}{|c|}{$\begin{array}{c}\text { Accounting Expertise } \\
(\text { ACC_ACFE }) \\
(n=160)\end{array}$} & \multicolumn{2}{|c|}{$\begin{array}{c}\text { Non-Accounting Expertise } \\
\text { (NONACC_ACFE) } \\
(\mathrm{n}=157)\end{array}$} & \\
\hline & $\underline{\mathrm{CFO}}$ & $\underline{\mathrm{CPA}}$ & $\begin{array}{c}\text { Other } \\
\text { Financial }^{\mathrm{c}} \\
\end{array}$ & $\begin{array}{c}\text { Senior } \\
\text { Executives }\end{array}$ & Other $^{d}$ & $\underline{\text { Total }}$ \\
\hline $\operatorname{SCM}(n=63)$ & 25 & 14 & 5 & 26 & 7 & 77 \\
\hline $\operatorname{NNM}(\mathrm{n}=83)$ & 47 & 16 & 2 & 37 & 8 & 110 \\
\hline NYSE $(n=80)$ & 31 & 15 & 5 & 67 & 12 & 130 \\
\hline Total $(n=226)$ & 103 & 45 & 12 & 130 & 27 & 317 \\
\hline
\end{tabular}

Panel B - Tenure on the Audit Committee

$\underline{\text { Firms with }}$

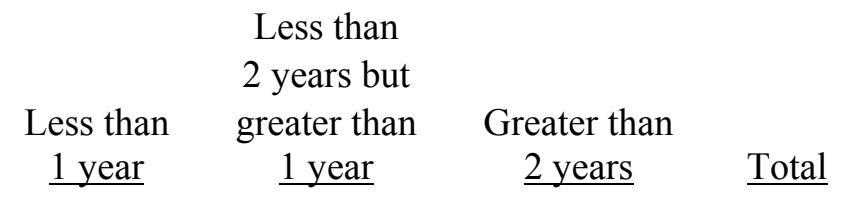

At least one ACC_ACFE $(n=141)$ :

ACC_ACFE tenure

NONACC_ACFE tenure

\begin{tabular}{ccc|c}
44 & 30 & 86 & 160 \\
8 & 6 & 20 & 34 \\
17 & & & \\
69 & 17 & 89 & 123 \\
\hline & 53 & 195 & 317
\end{tabular}

Total

At least one NONACC_ACFE

but no ACC_ACFE $(\mathrm{n}=85)$

69

${ }^{\mathrm{a}}$ Current and previous work experience was coded based on the highest position held. Several individuals held multiple positions such as CFO and VP-Finance. These individuals were coded as CFO.

${ }^{\mathrm{b}}$ SCM stands for Nasdaq Small Cap Market, NNM stands for Nasdaq National Market, and NYSE stands for New York Stock Exchange.

${ }^{\mathrm{c}}$ Indicates individuals who held the position of VP-Finance, treasurer, controller, and one individual who is a certified financial analyst.

${ }^{\mathrm{d}}$ Indicates individuals who held the position of venture capitalist, investment banker, consultant, private investor, academic, attorney, director, principal, retiree, and presidential advisor. 


\section{TABLE 2}

Descriptive Statistics for Earnings Management and Control Variables Mean (Median) [Standard Deviation]

\begin{tabular}{|c|c|c|c|c|c|c|c|}
\hline Variable $^{\mathrm{a}}$ & $\begin{array}{c}\text { Entire } \\
\text { Sample } \\
(\mathrm{n}=283) \\
\end{array}$ & $\begin{array}{c}\text { Accounting } \\
\text { ACFE Firms } \\
(\text { ACC_ACFE) } \\
(\mathrm{n}=141) \\
\end{array}$ & $\begin{array}{c}\text { Non-Accounting } \\
\text { ACFE Firms } \\
\text { (NONACC_ACFE) } \\
(\mathrm{n}=85)\end{array}$ & $\begin{array}{c}\text { No } \\
\text { ACFE Firms } \\
(\text { NOACFE }) \\
(n=57) \\
\end{array}$ & 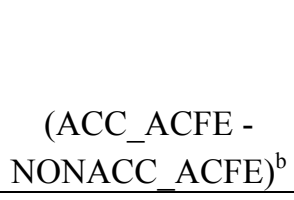 & $\begin{array}{c}\left(\mathrm{ACC} \_\mathrm{ACFE}-\right. \\
\mathrm{NOACFE})^{\mathrm{b}}\end{array}$ & $\begin{array}{c}\text { (NONACC_ACFE - }_{\text {NOACFE })^{b}} \\
\text { NOA }\end{array}$ \\
\hline ABS_PAC & $\begin{array}{r}0.112 \\
(0.056) \\
{[0.186]}\end{array}$ & $\begin{array}{r}0.092 \\
(0.051) \\
{[0.127]}\end{array}$ & $\begin{array}{r}0.124 \\
(0.065) \\
{[0.200]}\end{array}$ & $\begin{array}{r}0.145 \\
(0.058) \\
{[0.268]}\end{array}$ & $\begin{array}{r}-0.032 \\
(-0.013)\end{array}$ & $\begin{array}{l}-0.053^{*} \\
(-0.007)\end{array}$ & $\begin{array}{r}-0.021 \\
(0.006)\end{array}$ \\
\hline STRONGGOV & $\begin{array}{r}0.633 \\
(1.000) \\
{[0.483]}\end{array}$ & $\begin{array}{r}0.610 \\
(1.000) \\
{[0.490]}\end{array}$ & $\begin{array}{r}0.647 \\
(1.000) \\
{[0.481]}\end{array}$ & $\begin{array}{r}0.667 \\
(1.000) \\
{[0.476]}\end{array}$ & $\begin{array}{r}-0.037 \\
(0.000)\end{array}$ & $\begin{array}{r}-0.057 \\
(0.000)\end{array}$ & $\begin{array}{r}-0.020 \\
(0.000)\end{array}$ \\
\hline SIZE & $\begin{array}{r}3,510.884 \\
(225.051) \\
{[18,140.260]}\end{array}$ & $\begin{array}{r}2,347.849 \\
(237.931) \\
{[8,240.821]}\end{array}$ & $\begin{array}{r}6,900.863 \\
(357.527) \\
{[30,761.640]}\end{array}$ & $\begin{array}{r}1,332.631 \\
(160.147) \\
{[6,497.939]}\end{array}$ & $\begin{array}{l}-4,553.014 * \\
(-119.596)\end{array}$ & $\begin{array}{r}1,015.218 \\
(77.784)\end{array}$ & $\begin{array}{l}5,568.232 \\
(197.380)^{*}\end{array}$ \\
\hline $\mathrm{M} / \mathrm{B}$ & $\begin{array}{r}1.464 \\
(0.943) \\
{[2.281]}\end{array}$ & $\begin{array}{r}1.420 \\
(1.005) \\
{[1.301]}\end{array}$ & $\begin{array}{r}1.267 \\
(0.791) \\
{[1.193]}\end{array}$ & $\begin{array}{r}1.868 \\
(0.968) \\
{[4.427]}\end{array}$ & $\begin{array}{r}0.152 \\
(0.214)\end{array}$ & $\begin{array}{r}-0.448 \\
(0.036)\end{array}$ & $\begin{array}{r}-0.600 \\
(-0.178)\end{array}$ \\
\hline DISTRESS & $\begin{array}{r}-3.891 \\
(-4.046) \\
{[1.471]}\end{array}$ & $\begin{array}{r}-3.945 \\
(-4.208) \\
{[1.604]}\end{array}$ & $\begin{array}{r}-3.766 \\
(-3.892) \\
{[1.210]}\end{array}$ & $\begin{array}{r}-3.945 \\
(-3.919) \\
{[1.494]}\end{array}$ & $\begin{array}{c}-0.179 \\
(-0.316) *\end{array}$ & $\begin{array}{r}-0.000 \\
(-0.289)\end{array}$ & $\begin{array}{r}0.179 \\
(0.027)\end{array}$ \\
\hline $\mathrm{OCF}$ & $\begin{array}{r}0.020 \\
(0.073) \\
{[0.339]}\end{array}$ & $\begin{array}{r}0.049 \\
(0.071) \\
{[0.239]}\end{array}$ & $\begin{array}{r}0.012 \\
(0.074) \\
{[0.275]}\end{array}$ & $\begin{array}{l}-0.038 \\
(0.079) \\
{[0.565]}\end{array}$ & $\begin{array}{r}0.037 \\
(-0.004)\end{array}$ & $\begin{array}{r}0.086 \\
(-0.008)\end{array}$ & $\begin{array}{r}0.049 \\
(-0.005)\end{array}$ \\
\hline
\end{tabular}


TABLE 2 (continued)

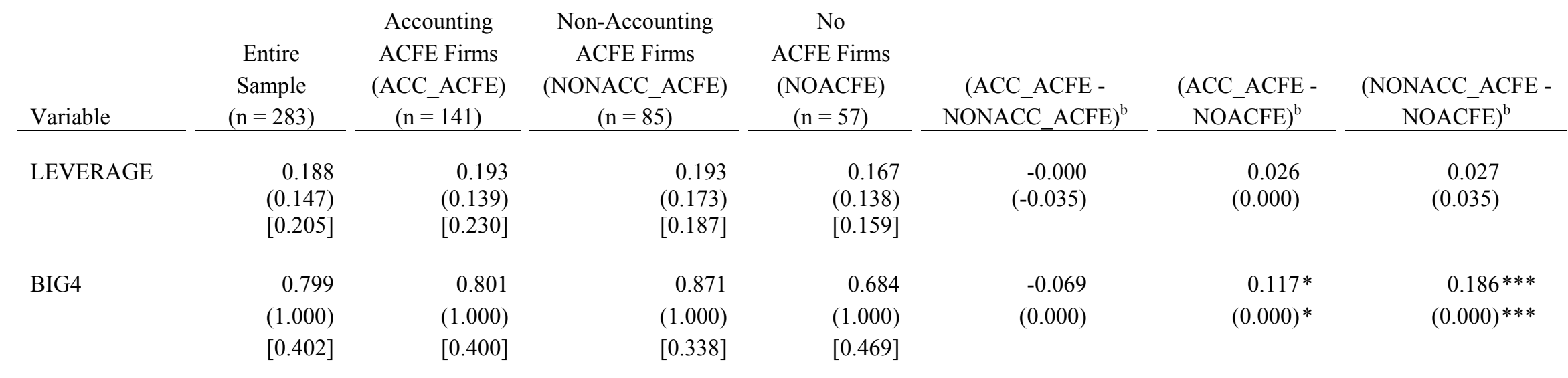

$\overline{* \text { and } * * * \text { indicate significance at } \mathrm{p}<0.10 \text { and } \mathrm{p}}<0.01$, respectively, based on two-tailed tests.

${ }^{a}$ Variable definitions:

ABS_PAC $=$ absolute value of the discretionary accrual measure adjusted for performance;

ACC_ACFE = 1 if firm has at least one accounting audit committee financial expert (ACFE), else 0;

NONACC_ACFE $=1$ if firm has at least one non-accounting ACFE, but no accounting ACFE, else 0;

STRONGGOV $=1$ if the summary measure of governance is greater than or equal to the sample median, else 0 ;

SIZE = firm's price per share at fiscal year end multiplied by the number of shares outstanding (in millions);

$\mathrm{M} / \mathrm{B}=$ market value of the total firm divided by the book value of assets, measured at the beginning of the fiscal year;

DISTRESS = Zmijewski's (1984) financial condition index;

OCF = cash flow from operations scaled by the beginning of the year total assets;

LEVERAGE = total debt divided by total assets;

BIG4 = 1 if the firm engaged one of the largest four audit firms, else 0 .

${ }^{\mathrm{b}}$ Test for differences in the means are based on t-statistics (Z-statistics) for continuous variables (proportions). Tests in differences in the median are based on Wilcoxon rank sum test. The Wilcoxon rank sum test tests whether the observations in the two groups are from populations with different medians. Thus, the test can indicate a significant difference even though the medians for the two groups are the same. 


\section{TABLE 3}

\section{Correlation Matrix $^{\text {a }}$}

\begin{tabular}{|c|c|c|c|c|c|c|c|c|}
\hline Variable $^{\mathrm{b}}$ & $\mathrm{ACC}$ ACFE & NONACC_ACFE & STRONGGOV & SIZE & $\mathrm{M} / \mathrm{B}$ & DISTRESS & $\mathrm{OCF}$ & LEVERAGE \\
\hline NONACC ACFE & $-0.6529 * * *$ & & & & & & & \\
\hline STRONGḠOV & -0.0467 & 0.0198 & & & & & & \\
\hline SIZE & 0.0240 & 0.0708 & $0.2525 * * *$ & & & & & \\
\hline $\mathrm{M} / \mathrm{B}$ & 0.0694 & -0.0876 & 0.0882 & 0.0799 & & & & \\
\hline DISTRESS & -0.0884 & 0.0922 & 0.0564 & -0.0358 & $0.1033 *$ & & & \\
\hline $\mathrm{OCF}$ & 0.0472 & -0.0119 & -0.0156 & $0.1586 * * *$ & $-0.6446 * * *$ & $-0.3221 * * *$ & & \\
\hline LEVERAGE & -0.0268 & 0.0453 & -0.0186 & $0.1154 *$ & -0.0837 & $0.7628 * * *$ & $0.1111 *$ & \\
\hline BIG4 & 0.0070 & $0.1176 * *$ & 0.0923 & $0.5056 * * *$ & 0.0112 & -0.0221 & 0.0505 & 0.0756 \\
\hline
\end{tabular}

$*, * *$, and $* * *$ indicate significance at $\mathrm{p}<0.10, \mathrm{p}<0.05$ and $\mathrm{p}<0.01$, respectively, based on two-tailed tests.

${ }^{a}$ We report Spearman rank correlation coefficients for ACC_ACFE, NONACC_ACFE, STRONGGOV, and BIG4 and Pearson correlations otherwise.

${ }^{\mathrm{b}}$ Variable definitions:

ACC_ACFE = 1 if firm has at least one accounting audit committee financial expert (ACFE), else 0;

NONACC_ACFE $=1$ if firm has at least one non-accounting ACFE, but no accounting ACFE, else 0;

$\mathrm{STRONGGOV}=1$ if the summary measure of governance is greater than or equal to the sample median, else 0 ;

SIZE = natural log of market value of equity;

$\mathrm{M} / \mathrm{B}=$ market value of the total firm divided by the book value of assets, measured at the beginning of the fiscal year;

DISTRESS = Zmijewski's (1984) financial condition index;

OCF = cash flow from operations scaled by the beginning of the year total assets;

LEVERAGE = total debt divided by total assets;

BIG4 = 1 if the firm engaged one of the largest four audit firms, else 0 . 


\section{TABLE 4}

\section{Regression of Earnings Management on Audit Committee Financial Expertise and Control Variables}

\begin{tabular}{|c|c|c|c|}
\hline Variable $^{\mathrm{a}}$ & $\begin{array}{l}\text { Exp. } \\
\text { Sign }\end{array}$ & $\begin{array}{c}\text { Estimated } \\
\text { Coefficients }\end{array}$ & \\
\hline Variable & & & t-statistic \\
\hline INTERCEPT & & -0.6252 & -1.05 \\
\hline ACFE & - & -0.6052 & $-1.93 * *$ \\
\hline STRONGGOV & - & -0.6785 & $-1.94 * *$ \\
\hline ACFE*STRONGGOV & $?$ & 0.7130 & $1.83 *$ \\
\hline SIZE & - & -0.0908 & $-2.16 * *$ \\
\hline $\mathrm{M} / \mathrm{B}$ & + & 0.0919 & $2.02 * *$ \\
\hline DISTRESS & + & 0.2339 & $2.23 * *$ \\
\hline OCF & - & 0.2960 & 0.79 \\
\hline LEVERAGE & - & -1.1167 & $-1.56 *$ \\
\hline BIG4 & - & -0.3425 & $-1.60 *$ \\
\hline$N$ & & 283 & \\
\hline$\chi^{2}$ & & 4.02 & \\
\hline p-value & & 0.0001 & \\
\hline Adjusted $\mathrm{R}^{2}$ & & 0.09 & \\
\hline
\end{tabular}

* and $* *$ indicate significance at $\mathrm{p}<0.10$ and $\mathrm{p}<0.05$, respectively, based on one-tailed (twotailed) tests for variables whose relation to the dependent variable is (is not) predicted.

${ }^{\text {a }}$ Variable definitions:

LN_ABS_PAC $=$ natural log of absolute value of performance adjusted discretionary accruals;

$\mathrm{ACFE}=1$ if the firm names at least one audit committee financial expert (ACFE), else 0 ;

STRONGGOV $=1$ if the summary measure of governance is greater than or equal to the sample median, else 0 ;

SIZE = natural log of market value of equity;

$\mathrm{M} / \mathrm{B}=$ market value of the total firm divided by the book value of assets, measured at the beginning of the fiscal year;

DISTRESS $=$ Zmijewski's (1984) financial condition index;

$\mathrm{OCF}=$ cash flow from operations scaled by the beginning of the year total assets;

LEVERAGE $=$ total debt divided by total assets;

BIG4 = 1 if the firm engaged one of the largest four audit firms, else 0. 


\section{TABLE 5}

\section{Regression of Earnings Management on Accounting and Non-Accounting Financial Expertise and Control Variables}

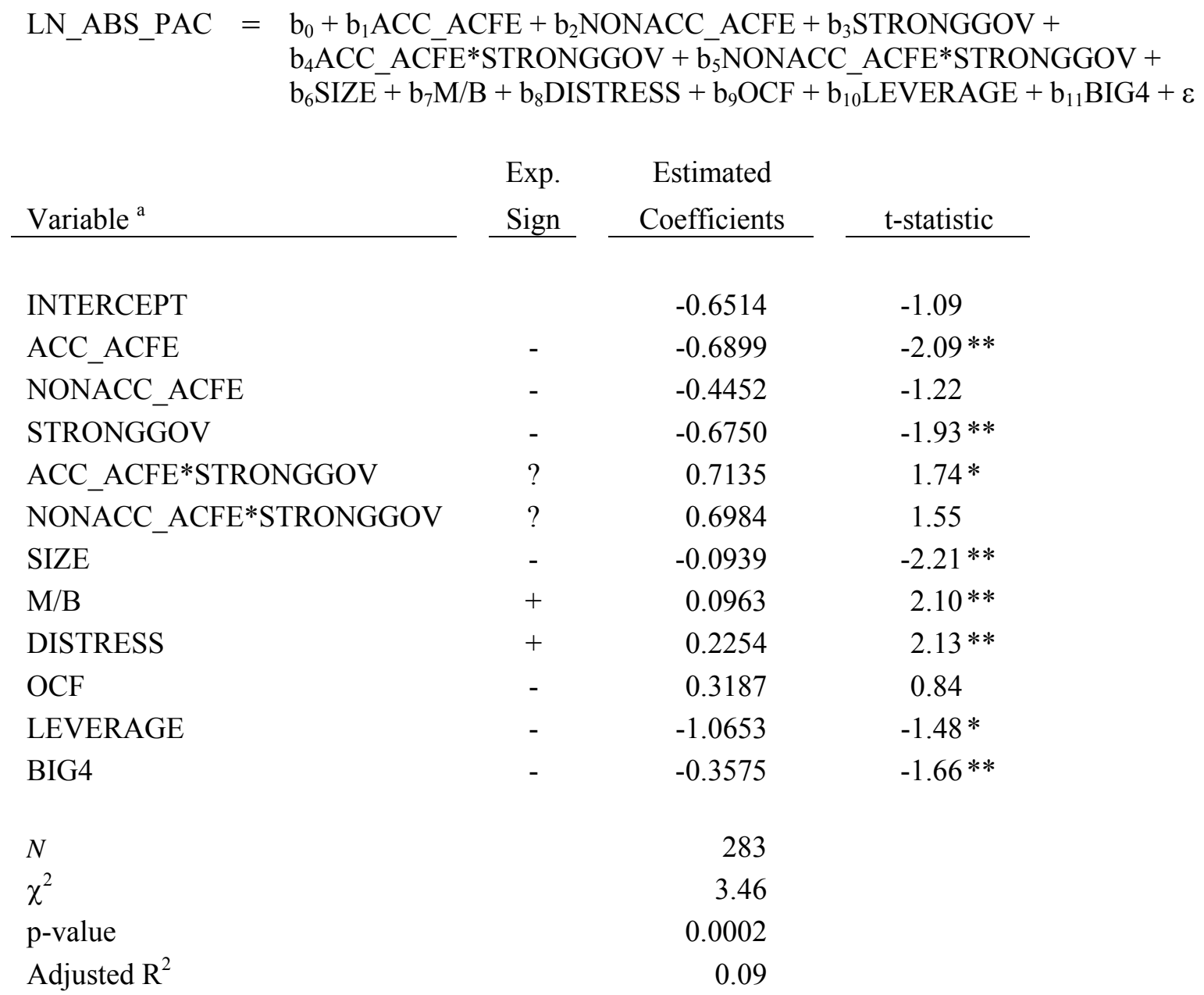

* and $* *$ indicate significance at $\mathrm{p}<0.10$ and $\mathrm{p}<0.05$, respectively, based on one-tailed (twotailed) tests for variables whose relation to the dependent variable is (is not) predicted. 


\section{TABLE 5 (continued)}

${ }^{\text {a }}$ Variable definitions:

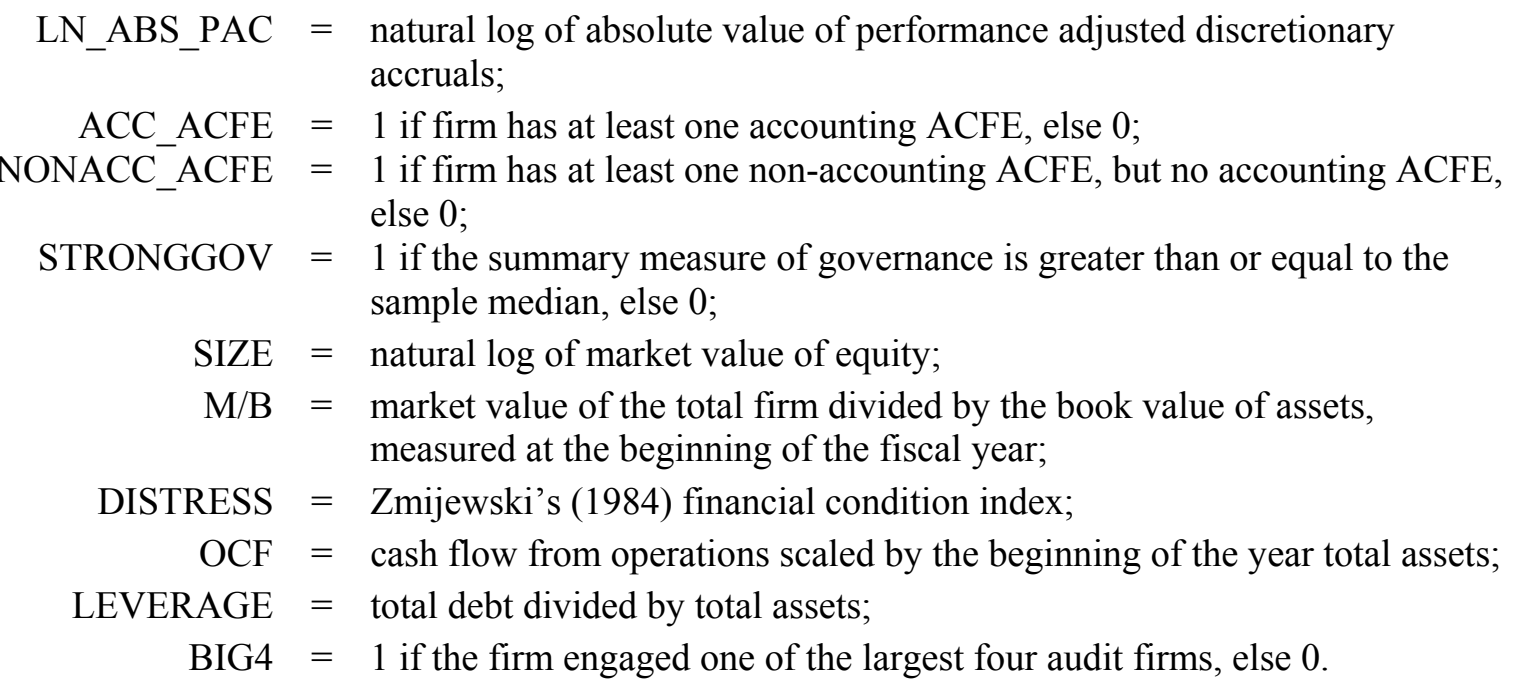


Table 6

\begin{tabular}{|c|c|c|c|}
\hline \multirow{3}{*}{$\begin{array}{ll}\mathrm{LN}_{-} \mathrm{ABS} \_\mathrm{PAC}= & \mathrm{b}_{0}+\mathrm{b}_{1} \mathrm{~A} \\
& \mathrm{~b}_{5} \mathrm{ACC} \\
& \mathrm{b}_{7} \mathrm{OTHE} \\
& +\mathrm{b}_{12} \mathrm{LE} \\
& \\
& \\
\text { Variable }^{\mathrm{a}} & \end{array}$} & \multicolumn{3}{|c|}{$\begin{array}{l}\begin{array}{l}\text { Regression of Earnings Management on Accounting Financial Experts, Senior Business } \\
\text { Executives, Other Non-Accounting Financial Expertise and Control Variables }\end{array} \\
\begin{aligned} \text { LN_ABS_PAC }= & \mathrm{b}_{0}+\mathrm{b}_{1} \mathrm{ACC} \text { ACFE }+\mathrm{b}_{2} \mathrm{EXEC}+\mathrm{b}_{3} \text { OTHER }+\mathrm{b}_{4} \text { STRONGGOV }+ \\
& \mathrm{b}_{5} \mathrm{ACC} A \mathrm{ACFE} \text { STTRONGGOV }+\mathrm{b}_{6} \text { EXEC*STRONGGOV }+ \\
& \mathrm{b}_{7} \mathrm{OTHER} * \mathrm{OTRONGGOV}+\mathrm{b}_{8} \mathrm{SIZE}+\mathrm{b}_{9} \mathrm{M} / \mathrm{B}+\mathrm{b}_{10} \mathrm{DISTRESS}+\mathrm{b}_{11} \mathrm{OCF} \\
& +\mathrm{b}_{12} \text { LEVERAGE }+\mathrm{b}_{13} \mathrm{BIG} 4+\varepsilon\end{aligned}\end{array}$} \\
\hline & Exp. & Estimated & \\
\hline & Sign & Coefficients & t-statistic \\
\hline \multicolumn{2}{|l|}{ INTERCEPT } & -0.6090 & -1.01 \\
\hline ACC_ACFE & - & -0.6889 & $-2.09 * *$ \\
\hline EXEC & $?$ & -0.2798 & -0.72 \\
\hline OTHER & $?$ & -0.9597 & $-1.75 *$ \\
\hline STRONGGOV & - & -0.6781 & $-1.93 * *$ \\
\hline ACC_ACFE*STRONGGOV & $?$ & 0.7227 & $1.76^{*}$ \\
\hline EXEC*STRONGGOV & $?$ & 0.5658 & 1.20 \\
\hline OTHER*STRONGGOV & $?$ & 0.9538 & 1.19 \\
\hline SIZE & - & -0.0939 & $-2.20 * *$ \\
\hline $\mathrm{M} / \mathrm{B}$ & + & 0.0920 & $1.99 * *$ \\
\hline DISTRESS & + & 0.2269 & $2.14 * *$ \\
\hline $\mathrm{OCF}$ & - & 0.2739 & 0.72 \\
\hline LEVERAGE & - & -1.0984 & $-1.53 *$ \\
\hline BIG4 & - & -0.3908 & $-1.80 * *$ \\
\hline \multicolumn{2}{|l|}{$N$} & 283 & \\
\hline$\chi^{2}$ & & 3.06 & \\
\hline p-value & & 0.0003 & \\
\hline Adjusted $\mathrm{R}^{2}$ & & 0.09 & \\
\hline
\end{tabular}

* and $* *$ indicate significance at $\mathrm{p}<0.10$ and $\mathrm{p}<0.05$, respectively, based on one-tailed (twotailed) tests for variables whose relation to the dependent variable is (is not) predicted. 


\section{TABLE 6 (continued)}

${ }^{\text {a }}$ Variable definitions:

LN_ABS_PAC $=$ natural log of absolute value of performance adjusted discretionary accruals;

ACC_ACFE $=1$ if firm has at least one accounting ACFE, else 0;

$\mathrm{EXEC}=1$ if firm has at least one non-accounting ACFE with current or previous experience as a CEO, President, Vice-President, or Chairman of the Board but no ACC_ACFE, else 0;

OTHER $=1$ if the firm has at least one non-accounting ACFE, but no ACC_ACFE or EXEC, else 0.

STRONGGOV $=1$ if the summary measure of governance is greater than or equal to the sample median, else 0 ;

$\mathrm{SIZE}=$ natural $\log$ of market value of equity;

$\mathrm{M} / \mathrm{B}=$ market value of the total firm divided by the book value of assets, measured at the beginning of the fiscal year;

DISTRESS $=$ Zmijewski's (1984) financial condition index;

OCF $=$ cash flow from operations scaled by the beginning of the year total assets;

LEVERAGE $=$ total debt divided by total assets;

BIG4 = 1 if the firm engaged one of the largest four audit firms, else 0. 


\section{TABLE 7}

\section{Regression of Earnings Management on Independent Accounting Financial Experts, Senior}

Business Executives, Other Non-Accounting Financial Expertise and Control Variables

\begin{tabular}{|c|c|c|c|}
\hline \multirow[b]{2}{*}{ Variable $^{a}$} & \multirow{2}{*}{$\begin{array}{l}\text { Exp. } \\
\text { Sign }\end{array}$} & \multicolumn{2}{|l|}{ Estimated } \\
\hline & & Coefficients & t-statistic \\
\hline INTERCEPT & & -0.4827 & -0.83 \\
\hline ACC_ACFE_IND & - & -0.8760 & $-2.87 * * *$ \\
\hline EXEC_IND & $?$ & -0.5166 & -1.42 \\
\hline OTHER_IND & $?$ & -1.2851 & $-2.27 * *$ \\
\hline STRONGGOV & - & -0.6882 & $-2.18 * *$ \\
\hline ACC_ACFE_IND*STRONGGOV & $?$ & 0.7355 & $1.92 *$ \\
\hline EXEC_IND*STRONGGOV & $?$ & 0.6087 & 1.37 \\
\hline OTHER_IND*STRONGGOV & $?$ & 1.1592 & 1.43 \\
\hline SIZE & - & -0.0825 & $-1.95 * *$ \\
\hline $\mathrm{M} / \mathrm{B}$ & + & 0.0849 & $1.85 *$ \\
\hline DISTRESS & + & 0.2345 & $2.23 * *$ \\
\hline OCF & - & 0.2509 & 0.66 \\
\hline LEVERAGE & - & -1.1874 & $-1.66 *$ \\
\hline BIG4 & - & -0.3810 & $-1.78 *$ \\
\hline$N$ & & 283 & \\
\hline$\chi^{2}$ & & 3.39 & \\
\hline p-value & & 0.0001 & \\
\hline Adjusted $\mathrm{R}^{2}$ & & 0.10 & \\
\hline
\end{tabular}

${ }^{*}, * *$, and $* * *$ indicate significance at $\mathrm{p}<0.10, \mathrm{p}<0.05$ and $\mathrm{p}<0.01$, respectively, based on onetailed (two-tailed) tests for variables whose relation to the dependent variable is (is not) predicted. 


\section{TABLE 7 (continued)}

${ }^{\text {a }}$ Variable definitions:

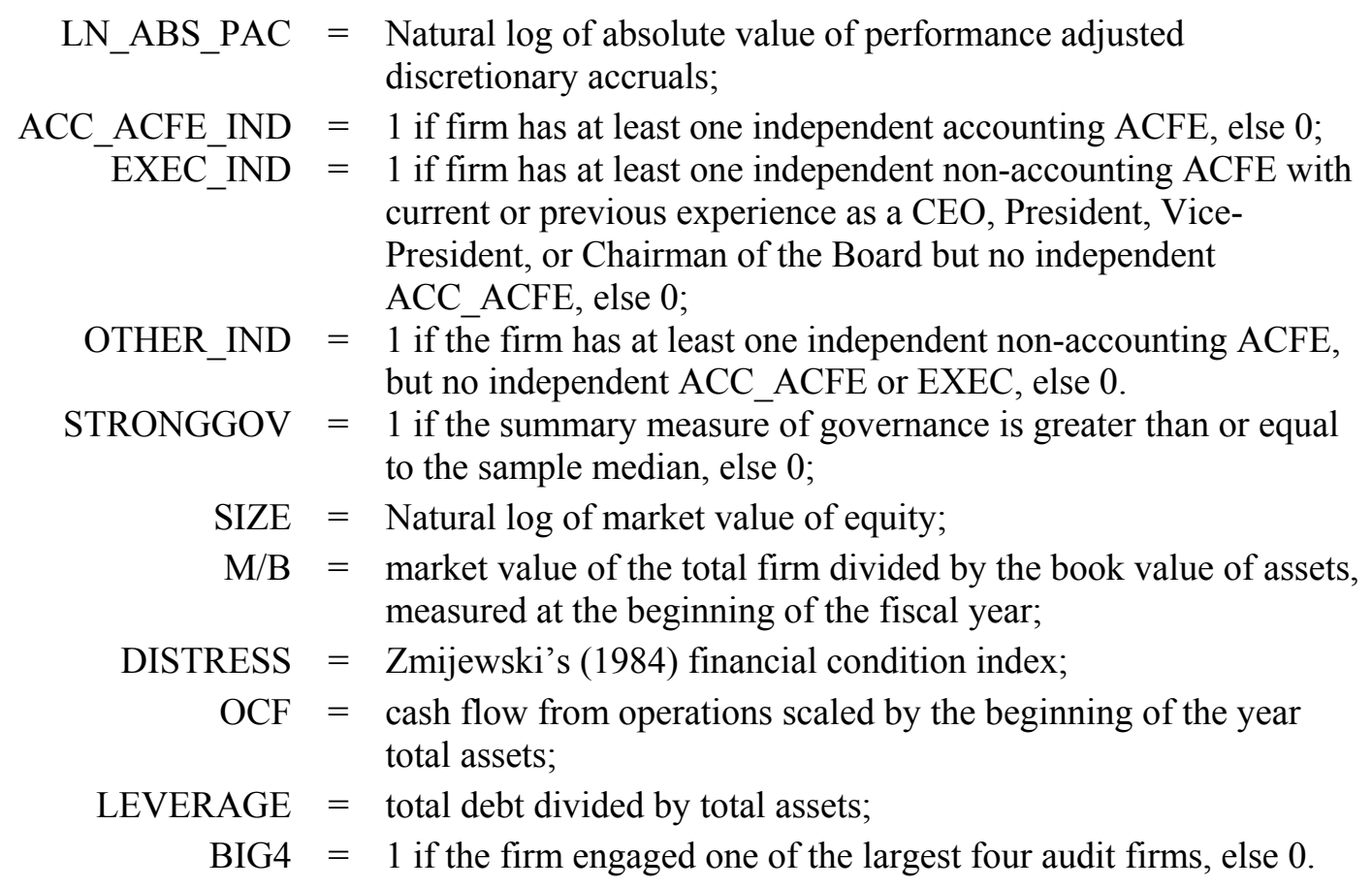




\section{TABLE 8}

\section{Regressions of Real Earnings Management on Audit Committee Financial Experts and Control Variables}

\begin{tabular}{|c|c|c|}
\hline \multirow{3}{*}{$\begin{array}{l}\text { PRODCOST } \\
\text { Variable }^{\mathrm{a}}\end{array}$} & \multicolumn{2}{|r|}{$\begin{array}{l}+\mathrm{b}_{3} \text { STRONGGOV }+ \\
\text { CC_ACFE*STRONGGOV }+ \\
-\mathrm{b}_{10} \text { DISCEXP }+\varepsilon\end{array}$} \\
\hline & \multicolumn{2}{|l|}{ Estimated } \\
\hline & Coefficients & t-statistic \\
\hline INTERCEPT & -0.1724 & -0.99 \\
\hline ACC_ACFE & 0.1719 & 1.08 \\
\hline NONACC_ACFE & 0.1379 & 0.80 \\
\hline STRONGGOV & 0.1515 & 0.90 \\
\hline ACC_ACFE*STRONGGOV & -0.0401 & -0.20 \\
\hline NONACC_ACFE*STRONGGOV & -0.0275 & -0.13 \\
\hline SIZE & 0.0060 & 0.32 \\
\hline OCF & -0.5710 & $-5.15 * * *$ \\
\hline BIG4 & -0.1546 & -1.50 \\
\hline ABSPAC & -0.7381 & $-3.53 * * *$ \\
\hline DISCEXP & -0.0912 & $-4.04 * * *$ \\
\hline Number of Observations & 280 & \\
\hline Chi-Square for Model & 5.67 & \\
\hline (degrees of freedom) & 10 & \\
\hline p-value & 0.0000 & \\
\hline Adjusted R-squared & 0.14 & \\
\hline
\end{tabular}




\section{TABLE 8 (continued)}

Panel B: Discretionary Expenditures

\begin{tabular}{|c|c|c|}
\hline \multirow[b]{2}{*}{ Variable $^{a}$} & \multicolumn{2}{|l|}{ Estimated } \\
\hline & Coefficients & t-statistic \\
\hline INTERCEPT & -1.4641 & $-3.26 * * *$ \\
\hline ACC_ACFE & 0.9584 & $2.32 * *$ \\
\hline NONACC_ACFE & 0.7426 & 1.64 \\
\hline STRONGGOV & 0.8272 & $1.89 *$ \\
\hline ACC_ACFE*STRONGGOV & -0.7935 & -1.54 \\
\hline NONACC_ACFE*STRONGGOV & -0.3197 & -0.57 \\
\hline SIZE & -0.0120 & -0.24 \\
\hline OCF & -1.5001 & $-5.15 * * *$ \\
\hline BIG4 & 0.3769 & 1.39 \\
\hline ABSPAC & 1.6061 & $2.91 * * *$ \\
\hline PRODCOST & -0.6286 & $-4.04 * * *$ \\
\hline Number of Observations & 280 & \\
\hline Chi-Square for Model & 7.10 & \\
\hline (degrees of freedom) & 10 & \\
\hline $\mathrm{p}$-value & 0.0001 & \\
\hline Adjusted R-squared & 0.18 & \\
\hline
\end{tabular}

$\bar{*}, * *$ and $* * *$ indicate significance at $\mathrm{p}<0.10, \mathrm{p}<0.05$ and $\mathrm{p}<0.01$, respectively, based on twotailed tests.

${ }^{\text {a }}$ Variable definitions:

PRODCOST $=$ the level of abnormal production costs, where production costs are defined as the sum of cost of goods sold and the change in inventories;

DISCEXP $=$ the level of abnormal discretionary expenditures, where discretionary expenses are the sum of advertising, expenses, R\&D expenses and SG\&A expenses;

ACC_ACFE $=1$ if firm has at least one accounting ACFE, else 0 ;

NONACC_ACFE $=1$ if firm has at least one non-accounting ACFE, but no accounting ACFE, else 0 ;

STRONGGOV $=1$ if the summary measure of governance is greater than or equal to the sample median, else 0 ;

SIZE = natural log of market value of equity;

OCF = cash flow from operations scaled by the beginning of the year total assets;

BIG4 = 1 if the firm engaged one of the largest four audit firms, else 0 ;

$\mathrm{ABSPAC}=$ the absolute value of performance adjusted discretionary accruals. 


\section{REFERENCES}

Abbott, L.J., Parker, S., Peters, G.F., 2004. Audit committee characteristics and restatements. Auditing: A Journal of Practice \& Theory 23 (1), 69-87.

Agrawal, A., Chadha, S., 2005. Corporate governance and accounting scandals. Journal of Law and Economics 43 (2), 371-406.

Anderson, R.C., Mansi, S.A., Reeb, D.M., 2004. Board characteristics, accounting report integrity, and the cost of debt. Journal of Accounting and Economics 37 (3), 315-342.

Baber, W.R., Fairfield, P.M., Haggard J.M., 1991. The effect of concern about reported income on discretionary spending decisions: the case of research and development. The Accounting Review 66 (4), 818-829.

Bartov, E., Gul, F.A., Tsui, J.S.L., 2000. Discretionary-accruals models and audit qualifications. Journal of Accounting and Economics 30 (3), 421-452.

Becker, C.L., DeFond, M.L., Jiambalvo, J., Subramanyam, K.R., 1998. The effect of audit quality on earnings management. Contemporary Accounting Research 15 (1), $1-24$.

Bédard, J., Chtourou, S.M., Courteau, L., 2004. The effect of audit committee expertise, independence, and activity on aggressive earnings management. Auditing: A Journal of Practice \& Theory 23 (2), 13-35.

Bhojraj, S., Sengupta, P., 2003. Effect of corporate governance on bond ratings and yields: The role of institutional investors and outside directors. Journal of Business 76 (3), 455-475.

Bushee, B., 1998. The influence of institutional investors on myopic R\&D investment behavior. The Accounting Review 73 (3), 305-333.

Carcello, J.V., Neal, T.L., 2000. Audit committee composition and auditor reporting. The Accounting Review 75 (4), 453-467.

, 2003. Audit committee characteristics and auditor dismissals following "new" going-concern reports. The Accounting Review 78 (1), 95-117.

Carver, B.T., 2005. Do firms adequately invest in the board of directors and its committees? Working Paper, University of Tennessee.

Coffee, J.C., Jr., 1991. Liquidity versus control: The institutional investor as corporate monitor. Columbia Law Review 91 (6), 1277-1368.

Cohen, D.A., Dey, A., Lys, T., 2005. Trends in Earnings Management in the Pre- and Post-Sarbanes Oxley Periods. Working Paper, New York University, University of Chicago, and Northwestern University. 
Core, J.E., Holthausen, R.W., Larcker, D.F., 1999. Corporate governance, chief executive officer compensation, and firm performance. Journal of Financial Economics 51 (3), 371-406.

Dechow, P.M., Sloan, R.G., Sweeney, A.P., 1995. Detecting earnings management. The Accounting Review 70 (2), 193-226.

Dechow, P.M., Sloan, R.G., Sweeney, A.P., 1996. Causes and consequences of earnings manipulation: an analysis of firms subject to enforcement actions by the SEC. Contemporary Accounting Research 13 (1), 1-36.

DeFond, M.L., Park, C., 1997. Smoothing income in anticipation of future earnings. Journal of Accounting and Economics 23 (2), 115-139.

DeFond, M.L., Francis, J.R., 2005. Audit research after Sarbanes-Oxley. Auditing: A Journal of Practice \& Theory (forthcoming).

DeFond, M.L., Hann, R.N., and Hu, X., 2005. Does the market value financial expertise on audit committees of boards of directors? Journal of Accounting Research 43 (2), 153-193.

Felo, A.J., Krishnamurthy, S., Solieri, S.A., 2003. Audit committee characteristics and the perceived quality of financial reporting: an empirical analysis. Working Paper, Pennsylvania State University - Great Valley, SUNY at Binghamton, and University of Scranton.

Francis, J., Maydew, E., Sparks, H.C., 1999. The role of Big 6 auditors in the credible reporting of accruals. Auditing: A Journal of Practice and Theory 18 (2), 17-34.

Frankel, R.M., Johnson, M.F., Nelson, K.K., 2002. The relationship between audit fees for nonaudit services and earnings quality. The Accounting Review 77 (Supplement), $71-105$.

Gompers, P.A., Ishii, J.L., Metrick, A., 2003. Corporate governance and equity prices. Quarterly Journal of Economics 118 (1), 107-155.

Graham J. R., Harvey, C.R., Raigopal, S., 2005. The economic implications of corporate financial reporting. Journal of Accounting and Economics 40 (1-3), 3-73.

, 2006. Value destruction and financial reporting decisions. Working paper, Duke University and University of Washington.

Gujarati, D.N., 1995. Basic Econometrics, $3^{\text {rd }}$ edition. McGraw-Hill, New York, NY.

Healy, P., 1985. The effect of bonus schemes on accounting decisions. Journal of Accounting and Economics 7 (1-3), 85-107. 
Holmstrom, B., Kaplan, S., 2003. The state of U.S. corporate governance: what's right and what's wrong? Journal of Applied Corporate Finance 15 (3), 8-20.

Jensen, M., 1993. Presidential address: the modern industrial revolution, exit and the failure of internal control systems. Journal of Finance 48 (3), 831-880.

Klein, A., 2002a. Audit committee, board of director characteristics, and earnings management. Journal of Accounting and Economics 33 (3), 375-400.

, 2002b. Economic determinants of audit committee independence. The Accounting Review 77 (2), 435-452.

, 2003. Likely effects of stock exchange governance proposals and Sarbanes-Oxley on corporate boards and financial reporting. Accounting Horizons 17 (4), 343-355.

Kothari, S.P., Leone, A.J., Wasley, C.E., 2005. Performance matched discretionary accrual measures. Journal of Accounting and Economics 39 (1), 163-197.

LaPorta, R., Lopez-de-Silanes, F., Shleifer, A., Vishny, R. 2002. Investor protection and corporate valuation. Journal of Finance 57 (3), 1147-1170.

Li, H., Pincus, M., Rego, S.O., 2006. Market reaction to events surrounding the SarbanesOxley Act of 2002. Working Paper, University of Iowa, University of California, Irvine, and University of Iowa.

Reynolds, J.K., Francis, J.R., 2000. Does size matter? The influence of large clients on office-level auditor-reporting decisions. Journal of Accounting and Economics 30 (3), $375-400$.

Ribstein, L., 2002. Market vs. regulatory responses to corporate fraud: a critique of the Sarbanes-Oxley Act of 2002. Journal of Corporation Law 28 (1), 1-67.

Romano, R., 2005. The Sarbanes-Oxley Act and the making of quack corporate governance. The Yale Law Journal 114 (7), 1521-1611.

Roychowdhury, S., 2005. Management of earnings through the manipulation of real activities that affect cash flow from operations. Working Paper, Massachusetts Institute of Technology.

Schipper, K., 1989. Commentary on earnings management. Accounting Horizons 3 (4), 91-102.

Sarbanes-Oxley Act of 2002, (SOX) Public Law 107-204, 107th Congress, 2d Session, July 24, 2002. Available on Congress.gov.

SEC, 2002. Proposed Rule: Disclosure Required by Sections 404, 406 and 407 of the Sarbanes-Oxley Act of 2002, Release Nos. 33-8138; 34-46701, October 22, 2002. Available on SEC.gov. 
SEC, 2003a. Disclosure Required by Sections 406 and 407 of the Sarbanes-Oxley Act of 2002, Release Nos. 33-8177; 34-47235, January 23, 2003. Available on SEC.gov.

SEC, 2003b. Disclosures Required by Section 406 and 407 of the Sarbanes-Oxley Act of 2002; Correction, Release Nos. 33-8177A; 34-47235A, March 26, 2003. Available on SEC.gov.

SEC, 2003c. Standards Relating to Listed Company Audit Committees, Release Nos. 338220, 34-47654, April 9, 2003. Available on SEC.gov.

Shleifer, A., Vishny, R., 1986. Large shareholders and corporate control. Journal of Political Economy 94 (3), 461-489.

U.S. Senate, 2002. Public Company Accounting Reform and Investor Protection Act of 2002, Report 107-205, 107th Congress, 2d Session, June 26, 2002. Available on Senate.gov.

Warfield, T.D., Wild, J.J., Wild, K.L., 1995. Managerial ownership, accounting choices, and informativeness of earnings. Journal of Accounting and Economics 20 (1), 6192.

Weisbach, M.S., 1988. Outside directors and CEO turnover. Journal of Financial Economics 20 (1-2), 431-460.

Xie, B., Davidson, W.N., DaDalt, P.J., 2003. Earnings management and corporate governance: the role of the board and the audit committee. Journal of Corporate Finance 9 (3), 295-316.

Yermack, D., 1996. Higher market valuation of companies with a small board of directors. Journal of Financial Economics 40 (2), 185-211.

Zhang, I.X., 2005. Economic consequences of the Sarbanes-Oxley Act of 2002. Joint Center: AEI-Brookings Joint Center for Regulatory Studies.

Zmijewski, M.E., 1984. Methodological issues related to the estimation of financial distress prediction models. Journal of Accounting Research 22 (Supplement), 59-82. 